Delineation of Recharge Areas for Selected Wells in the

St. Peter-Prairie du Chien-Jordan Aquifer, Rochester, Minnesota

United States

Geological

Survey

Water-Supply

Paper 2397

Prepared in cooperation with the U.S. Environmental Protection Agency

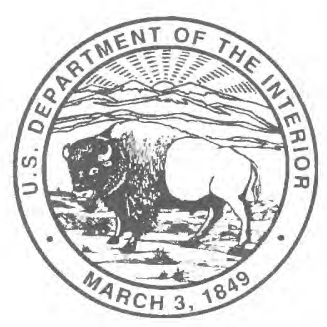




\section{AVAILABILITY OF BOOKS AND MAPS OF THE U.S. GEOLOGICAL SURVE)}

Instructions on ordering publications of the U.S. Geological Survey, along with prices of the last offerings, are given in current-year issues of the monthly catalog "New Publications of the U.S. Geological Survey." Prices of available U.S. Geolog. Survey publications released prior to the current year are listed in the most recent annual "Price and Availability List." Publicati that may be listed in various U.S. Geological Survey catalogs (see back inside cover) but not listed in the most recent annual "Ps and Availability List" may be no longer available.

Prices of reports released to the open files are given in the listing "U.S. Geological Survey Open-File Reports," upd monthly, which is for sale in microfiche from U.S. Geological Survey ESIC-Open-File Report Sales, Box 25286, Denver, 80225. Reports released through the NTIS may be obtained by writing to the National Technical Information Service, $L$ Department of Commerce, Springfield, VA 22161; please include NTIS report number with inquiry.

Order U.S. Geological Survey publications by mail or over the counter from the offices given below.

\section{BY MAIL}

\section{Books}

Professional Papers, Bulletins, Water-Supply Papers, Techniques of Water-Resources Investigations, Circulars, publications of general interest (such as leaflets, pamphlets, booklets), single copies of Earthquakes \& Volcanoes, Preliminary Determination of Epicenters, and some miscellaneous reports, including some of the foregoing series that have gone out of print at the Superintendent of Documents, are obtainable by mail from

\section{U.S. Geological Survey, Map Distribution Box 25286, Bldg. 810, Federal Center Denver, CO 80225}

Subscriptions to periodicals (Earthquakes \& Volcanoes and Preliminary Determination of Epicenters) can be obtained ONLY from the

\section{Superintendent of Documents \\ Government Printing Office \\ Washington, D.C. 20402}

(Check or money order must be payable to Superintendent of Documents.)

Maps

For maps, address mail orders to

\section{U.S. Geological Survey, Map Distribution Box 25286, Bldg. 810, Federal Center Denver, CO 80225}

Residents of Alaska may order maps from

\author{
U.S. Geological Survey, Earth Science Information Center \\ 101 Twelfth Ave. - Box 12 \\ Fairbanks, AK 99701
}

\section{OVER THE COUNTER}

\section{Books and Maps}

Books and maps of the U.S. Geological Survey are availa over the counter at the following U.S. Geological Survey offices, al which are authorized agents of the Superintendent of Documents:

- ANCHORAGE, Alaska-Rm. 101, 4230 University Dr.

- LAKEWOOD, Colorado-Federal Center, Bldg. 810

- MENLO PARK, California-Bldg. 3, Rm. 3128, 345 Mid field Rd.

- RESTON, Virginia-USGS National Center, Rm. 1C402, 12' Sunrise Valley Dr.

- SALT LAKE CITY, Utah-Federal Bldg., Rm. 8105, 125 So State St.

- SPOKANE, Washington-U.S. Post Office Bldg., Rm. 1 West 904 Riverside Ave.

- WASHINGTON, D.C.-Main Interior Bldg., Rm. 2650, and C Sts., NW.

\section{Maps Only}

Maps may be purchased over the counter at the following $U$ Geological Survey offices:

- FAIRBANKS, Alaska-New Federal Bldg., 101 Twelfth Av

- ROLLA, Missouri-1400 Independence Rd.

- STENNIS SPACE CENTER, Mississippi-Bldg. 3101 


\title{
Delineation of Recharge Areas for Selected Wells in the St. Peter-Prairie du Chien-Jordan Aquifer, Rochester, Minnesota
}

\author{
By G.N. DELIN and J.E. ALMENDINGER
}




\title{
U.S. DEPARTMENT OF THE INTERIOR BRUCE BABBITT, Secretary
}

\author{
U.S. GEOLOGICAL SURVEY
}

Robert M. Hirsch, Acting Director

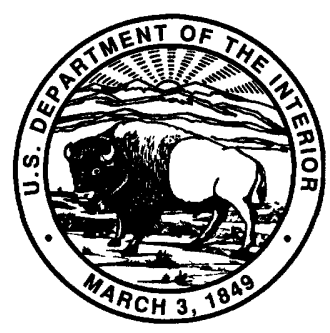

Any use of trade, product, or firm names in this publication is for descriptive purposes only and does not imply endorsement by the U.S. Government

For sale by

U.S. Geological Survey, Map Distribution

Box 25286, MS 306, Federal Center

Denver, CO 80225

\section{Library of Congress Cataloging in Publication Data}

Delin, G.N.

Delineation of recharge areas for selected wells in the St. Peter-Prairie du Chien-Jordan aquifer, Rochester, Minnesota / by G.N. Delin and J.E. Almendinger.

p. $\quad$ cm. - (U.S. Geological Survey water-supply paper ; 2397) "I 19.13:2392."

Prepared in cooperation with the U.S. Environmental Protection Agency. Includes bibliographical references.

1. Water, Underground-Minnesota-Rochester-Artificial recharge-Mathematical models. 2. Groundwater flow-Minnesota-Rochester-Mathematical models. I. Almendinger, James Edward. II. Geological Survey (U.S.) III. United States. Environmental Protection Agency. IV. Title. V. Series.

TD225. R59D44 1993

$627^{\prime} .56^{\prime} 09776155-\mathrm{dc} 20$ 


\section{CONTENTS}

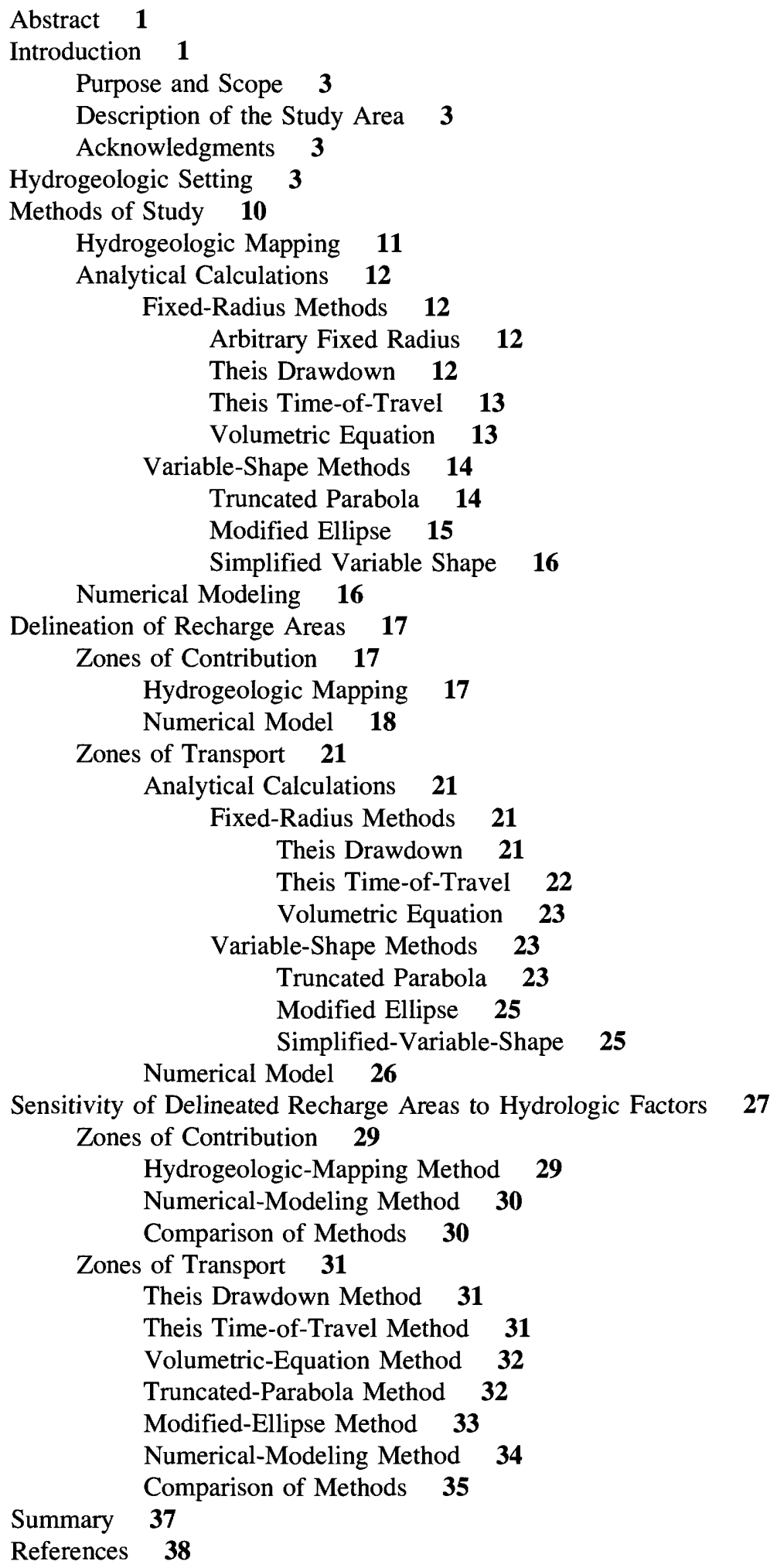

Zones of Contribution 29

Hydrogeologic-Mapping Method 29

Numerical-Modeling Method $\mathbf{3 0}$

Comparison of Methods $\mathbf{3 0}$

Zones of Transport $\mathbf{3 1}$

Theis Drawdown Method 31

Theis Time-of-Travel Method 31

Volumetric-Equation Method 32

Truncated-Parabola Method 32

Modified-Ellipse Method 33

Numerical-Modeling Method 34

Comparison of Methods 35

Summary

37

References 


\section{FIGURES}

1. Diagram showing areas of potential recharge to a well $\mathbf{2}$

2. Map showing location of study area and extent of numerical model 4

3. Generalized hydrogeologic column of regional aquifers and confining units 5

4. Map showing bedrock hydrogeology 6

5. Generalized hydrogeologic section $\mathrm{A}-\mathrm{A}^{\prime}$ through the study area 7

6-9. Maps showing:

6. Zones of contribution based on hydrogeologic mapping, highgradient conditions $\mathbf{8}$

7. Zones of contribution based on hydrogeologic mapping, low-gradient conditions 9

8. Location of high-capacity wells in the study area $\mathbf{1 0}$

9. Finite-difference grid for the numerical model 19

10. Zones of contribution computed by use of the numerical model, all wells pumped 20

11. Block diagram showing conceptualized ground-water flow from the top of the St. Peter-Prairie du Chien-Jordan aquifer to well $11 \quad 21$

12. Map showing zones of contribution computed by use of the numerical model, only wells 11 and 26 pumped 22

13. Map showing zones of influence based on the Theis drawdown method, 5-foot drawdown limit 23

14-19. Maps showing zones of transport based on the:

14. Theis time-of-travel method $\mathbf{2 4}$

15. Volumetric-equation method $\mathbf{2 5}$

16. Truncated-parabola method, uniform-flow travel time $\mathbf{2 6}$

17. Truncated-parabola method, Theis travel time $\mathbf{2 7}$

18. Modified-ellipse method $\mathbf{2 8}$

19. Numerical model 29

20. Map showing 10-year zones of transport for well $11 \quad 36$

\section{TABLES}

1. Data requirements for the zone-delineation methods $\mathbf{1 1}$

2. Hydrologic factors for the areas around wells used in the recharge-area calculations 17

3. Summary of recharge areas computed by use of each method $\mathbf{3 0}$

4. Sensitivity of radii of zones of influence to changes in hydrologic factors, Theis drawdown method $\mathbf{3 2}$

5. Sensitivity of radii of zones of transport to changes in hydrologic factors, Theis time-of-travel method $\mathbf{3 2}$

6. Sensitivity of radii of zones of transport to changes in hydrologic factors, volumetric-equation method $\mathbf{3 2}$

7. Sensitivity of distance to the stagnation point downgradient from a well computed for the calculated zones of contribution to changes in hydrologic factors, truncated-parabola method $\mathbf{3 3}$

8. Sensitivity of distance of travel to changes in hydrologic factors, uniform-flow procedure for truncated-parabola method $\mathbf{3 3}$

9. Sensitivity of distance between well and upgradient boundary of zone of transport to changes in hydrologic factors, modified-ellipse method $\mathbf{3 3}$

10. Sensitivity of zone-of-transport areas to changes in hydrologic factors, numericalmodeling method $\mathbf{3 4}$ 


\section{CONVERSION FACTORS AND VERTICAL DATUM}

For readers who wish to convert measurements from the inch-pound system of units used in this report to the metric system of units, the conversion factors are listed below.

\begin{tabular}{|c|c|c|}
\hline Multiply inch-pound units & By & To obtain metric unit \\
\hline $\begin{array}{r}\text { acre } \\
\text { foot }(\mathrm{ft}) \\
\text { foot per day }(\mathrm{ft} / \mathrm{d}) \\
\text { foot }^{2} \text { per day }\left(\mathrm{ft}^{2} / \mathrm{d}\right) \\
\text { foot }^{3} \text { per second }\left(\mathrm{ft}^{3} / \mathrm{s}\right) \\
\text { gallon }(\mathrm{gal}) \\
\text { gallon per minute }(\mathrm{gal} / \mathrm{min}) \\
\text { million gallons per year }(\mathrm{Mgal} / \mathrm{yr}) \\
\text { inch }(\mathrm{in} .) \\
\text { inch per year }(\mathrm{in} . / \mathrm{yr}) \\
\text { mile }(\mathrm{mi}) \\
\mathrm{mile}^{2}\left(\mathrm{mi}^{2}\right)\end{array}$ & $\begin{array}{c}4,047 \\
0.3048 \\
0.3048 \\
0.09294 \\
0.02832 \\
3.785 \\
0.06309 \\
0.00012 \\
25.4 \\
25.4 \\
1.609 \\
2.590\end{array}$ & $\begin{array}{l}\operatorname{meter}^{2}\left(\mathrm{~m}^{2}\right) \\
\text { meter }(\mathrm{m}) \\
\text { meter per day }(\mathrm{m} / \mathrm{d}) \\
\text { meter }^{2} \text { per day }\left(\mathrm{m}^{2} / \mathrm{d}\right) \\
\text { meter }^{3} \text { per second }\left(\mathrm{m}^{3} / \mathrm{s}\right) \\
\text { liter }(\mathrm{L}) \\
\text { liter per second }(\mathrm{L} / \mathrm{s}) \\
\text { meter }{ }^{3} \text { per second }\left(\mathrm{m}^{3} / \mathrm{s}\right) \\
\text { millimeter }(\mathrm{mm}) \\
\text { millimeter per year }(\mathrm{mm} / \mathrm{yr}) \\
\text { kilometer }(\mathrm{km}) \\
\text { kilometer }^{2}\left(\mathrm{~km}^{2}\right)\end{array}$ \\
\hline
\end{tabular}

Sea level: In this report the term "sea level" refers to the National Geodetic Vertical Datum of 1929-geodetic datum derived from a general adjustment of the first-order level nets of the United States and Canada, formerly called Sea Level Datum of 1929. 


\title{
Delineation of Recharge Areas for Selected Wells in the St. Peter-Prairie du Chien-Jordan Aquifer, Rochester, Minnesota
}

\author{
By G.N. Delin and J.E. Almendinger
}

\begin{abstract}
Accurate delineation of recharge areas for wells is an important requisite to protecting ground-water quality. Zones of transport and zones of contribution are two types of recharge areas that can be delineated. Analyticalcalculation, numerical-modeling, and hydrogeologicmapping methods were used to delineate recharge areas for two high-capacity wells (greater than about 200 gallons per minute discharge) completed in a karstic aquifer in the city of Rochester, in southeastern Minnesota. One well is less than 1,000 feet from a river in an area where the aquifer is unconfined, whereas the other well is more than 2,000 feet from a stream in an area where a bedrock confining unit is present.

Ground-water travel times from points along the top of the aquifer to a pumped well are identified by use of a constructed map showing lines of equal advective travel time. A zone of transport, therefore, is defined by the area bounded by lines of equal travel time. Zones of transport are delineated by analytical models (calculations) and by numerical models that account for hydrologic factors. Analytical models that were used include fixed-radius (Theis drawdown, Theis time-of-travel, and volumetric equation) and variable shape. Numerical modeling was done with the U.S. Geological Survey three-dimensional ground-water-flow model MODFLOW and particletracking code MODPATH. The zone-of-transport areas for each of the two wells calculated by the various analytical models were very similar. The Theis-drawdown method yielded results that compared least favorably with results from the other analytical methods. The zone-of-transport areas computed by use of the numerical model were generally larger than areas computed by use of analytical models.
\end{abstract}

Hydrogeologic mapping and numerical modeling were used to delineate zones of contribution to wells, defined as all parts of a ground-water-flow system that could supply water to a well. The zones of contribution delineated by use of numerical modeling have similar orientation (parallel to regional flow directions) but significantly different areas than the zones of contribution delineated by use of hydrogeologic mapping. Differences in computed areas of recharge are attributed to the capability of the numerical model to more accurately represent (1) the three-dimensional flow system, (2) hydrologic boundaries such as streams, (3) variable recharge, and (4) the influence of nearby pumped wells, compared to the analytical models.

\section{INTRODUCTION}

Protection of ground-water quality in areas of karst topography is of particular concern to water managers. Contaminants can easily enter the ground-water system in these areas through enlarged fractures and other karst features and can quickly move to wells. Accurate delineation of areas contributing ground water to wells is important for protecting ground-water quality.

The Wellhead Protection Program is a provision in the 1986 Amendments to the Safe Drinking Water Act designed to assist State agencies in protecting areas surrounding wells against infiltration, percolation, and transport of contaminants that may have adverse effects on human health. The U.S. Environmental Protection Agency (EPA) prepared a guidebook (U.S. Environmental Protection Agency, 1987) to provide technical guidance on the hydrologic aspects of wellhead protection in the United States. The parts of the land surface surrounding a well that are considered relevant to wellhead protection have been categorized as three types of recharge areas (fig. 1): the zone of transport, the zone of contribution, and the zone of influence (U.S. Environmental Protection Agency, 1987). The time required for a contaminant to travel between points in an aquifer can be identified by use of constructed maps showing lines of equal advective travel time. A zone of transport, therefore, is defined by the area around a pumped well bounded by lines of equal travel time. The zone of contribution for a high-capacity well (greater than about $200 \mathrm{gal} / \mathrm{min}$ discharge) is defined as that part of a ground-water-flow system supplying water to a well. The zone of contribution could be thought of as a zone of 


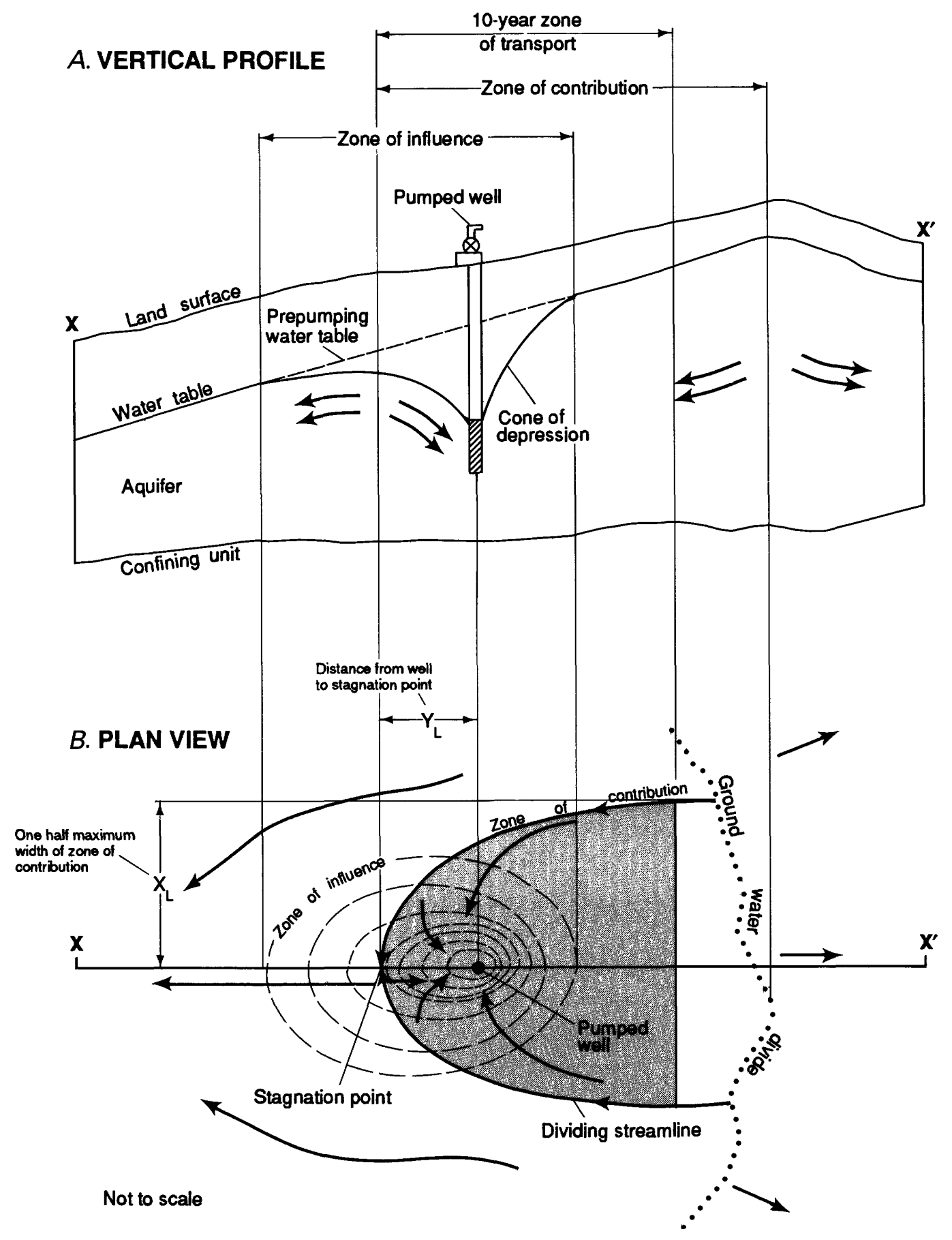

\section{EXPLANATION}

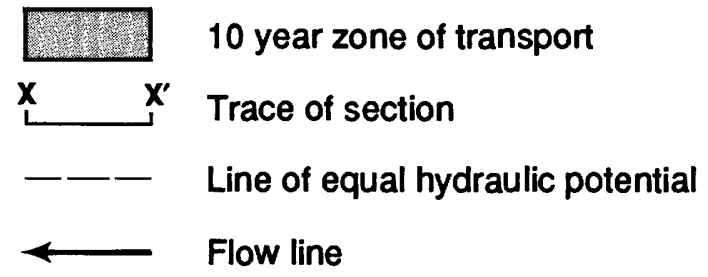

Figure 1. Areas of potential recharge to a well. (Modified from U.S. Environmental Protection Agency, 1987, fig. 2-7.) 
transport for infinite travel time. The zone of influence is the area of declines in hydraulic head resulting from the withdrawal of water from a well.

Methods for delineating recharge areas to wells (U.S. Environmental Protection Agency, 1987) range from simple techniques, such as specifying a circular area around a well, to complex numerical ground-water-flow models. For most water managers, use of complex models is impractical for defining recharge areas. Results of previous U.S. Geological Survey (USGS) studies have provided information on delineating recharge areas to a pumped well in glacial-drift and river-valley aquifers (Brown, 1963; Morrissey, 1987). Information comparing estimates of recharge areas for wells in karst terrain by use of available methods, however, is lacking. Consequently, the USGS in cooperation with the EPA began a study for evaluating techniques for delineating recharge areas, including use of a numerical ground-waterflow model and simpler methods, for selected wells in the karstic southeastern part of Minnesota. The objectives of the study were to (1) determine the effects of hydrogeologic conditions, aquifer characteristics, and well construction on the shape and size of computed recharge areas and (2) estimate conceptual errors in delineating recharge areas caused by oversimplified assumptions about aquifer characteristics and well construction.

The city of Rochester (fig. 2) is in an area of Minnesota considered to be susceptible to ground-water contamination because of thin soil cover and karst terrain. The city obtains its water supply from wells completed in a sandstone, limestone, and dolomite aquifer that underlies the city. A numerical ground-water-flow model was constructed as part of a previous USGS investigation (Delin, 1990) in the Rochester area. The availability of this model provided an opportunity to evaluate the sensitivity of delineated recharge areas to hydrologic factors for highcapacity wells completed in a karst aquifer.

\section{Purpose and Scope}

This report presents estimates of recharge areas, delineated by methods that differ in degree of complexity and accuracy, for selected municipal wells in Rochester. Specifically, the report describes the hydrologic theory and compares the results for several methods of delineating zones of contribution to wells, and of delineating 1-, 5-, and 10 -year zones of transport. The report describes the hydrologic factors that affect the shape and size of the zones. The area, shape, and orientation of the zones of transport are compared for each of the delineation methods.

\section{Description of the Study Area}

The study area is in Olmsted County in southeastern Minnesota and covers about 110 square miles $\left(\mathrm{mi}^{2}\right)$ from the city of Rochester to the south and west (fig. 2). The area is drained by the South Fork Zumbro River, a tributary of the Mississippi River. Topography is rolling to undulating in upland areas and steep near streams. Mean annual precipitation is about 27.5 inches (in.) (Baker and Kuehnast, 1978), most of which falls from May through September.

\section{Acknowledgments}

The authors acknowledge the Minnesota Department of Health for advice and assistance provided during this study. Thanks is also given to Rochester Public Utilities for providing data on the Rochester municipal wells.

\section{HYDROGEOLOGIC SETTING}

The sequence of sedimentary rocks in the Rochester area (fig. 3) has been divided into hydrogeologic units of regional aquifers and confining units (Delin and Woodward, 1984; Balaban, 1988). The city of Rochester obtains most of its municipal water supply from wells in the St. Peter-Prairie du Chien-Jordan aquifer. This aquifer is composed of the St. Peter Sandstone, the Prairie du Chien Group of limestones and dolomites, and the Jordan Sandstone. These individual formations are hydraulically connected, without an intervening confining unit and, therefore, are considered to be one aquifer. The St. Peter Sandstone is a fine- to medium-grained sandstone that is well sorted and poorly cemented and has an average thickness of about 100 feet (ft) (Balaban, 1988). The underlying Prairie du Chien Group is an argillaceous thinto thick-bedded limestone and dolomite that has an average thickness of about $300 \mathrm{ft}$. Karst features such as sinkholes, caves, and solution channels are common in the Prairie du Chien Group throughout the area (Balaban, 1988). The underlying Jordan Sandstone is a fine- to medium-grained sandstone that is friable to well cemented and has an average thickness of about $100 \mathrm{ft}$. Transmissivity of the $\mathrm{St}$. Peter and Jordan parts of the aquifer ranges from about 200 to 5,000 square feet per day $\left(\mathrm{ft}^{2} / \mathrm{d}\right)$ (Delin, 1990). Flow of water in the St. Peter and Jordan parts of the aquifer is primarily intergranular.

Transmissivity of the karstic Prairie du Chien Group is highly variable because of secondary permeability caused by fractures and solution cavities. The Prairie du Chien Group transmits water primarily through fractures, joints, and solution channels. Data on ground-water seepage to streams, lineaments, and joint-fractures indicate that the Prairie du Chien Group is anisotropic (Ruhl, 1989). Results of an aquifer test in Rochester also suggest that the Prairie du Chien Group is anisotropic (J.F. Ruhl, U.S. Geological Survey, written commun., 1989). Transmissivity of the Prairie du Chien Group typically ranges from 300 

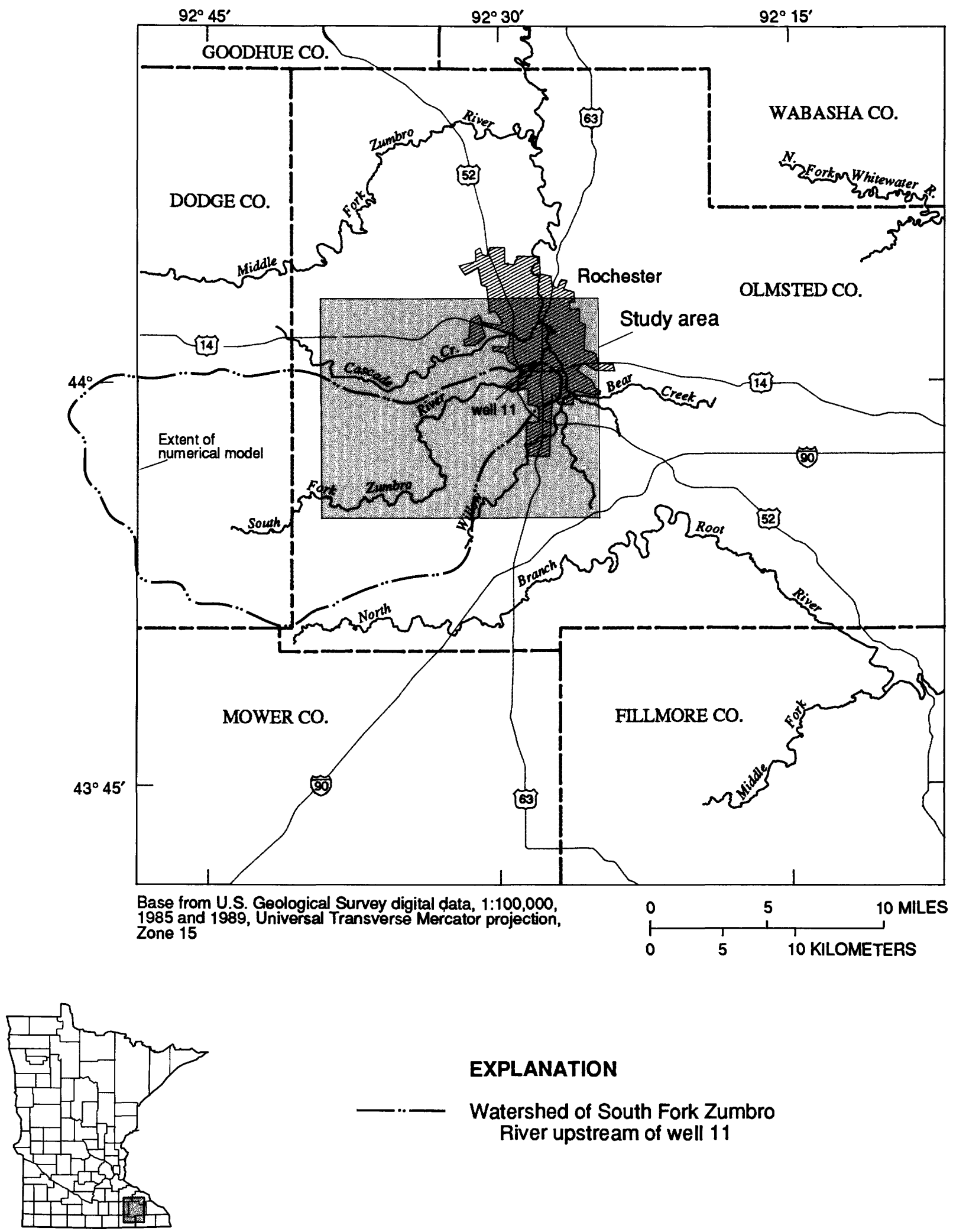

EXPLANATION

_... Watershed of South Fork Zumbro

River upstream of well 11

Study area location

Figure 2. Location of study area and extent of numerical model. 


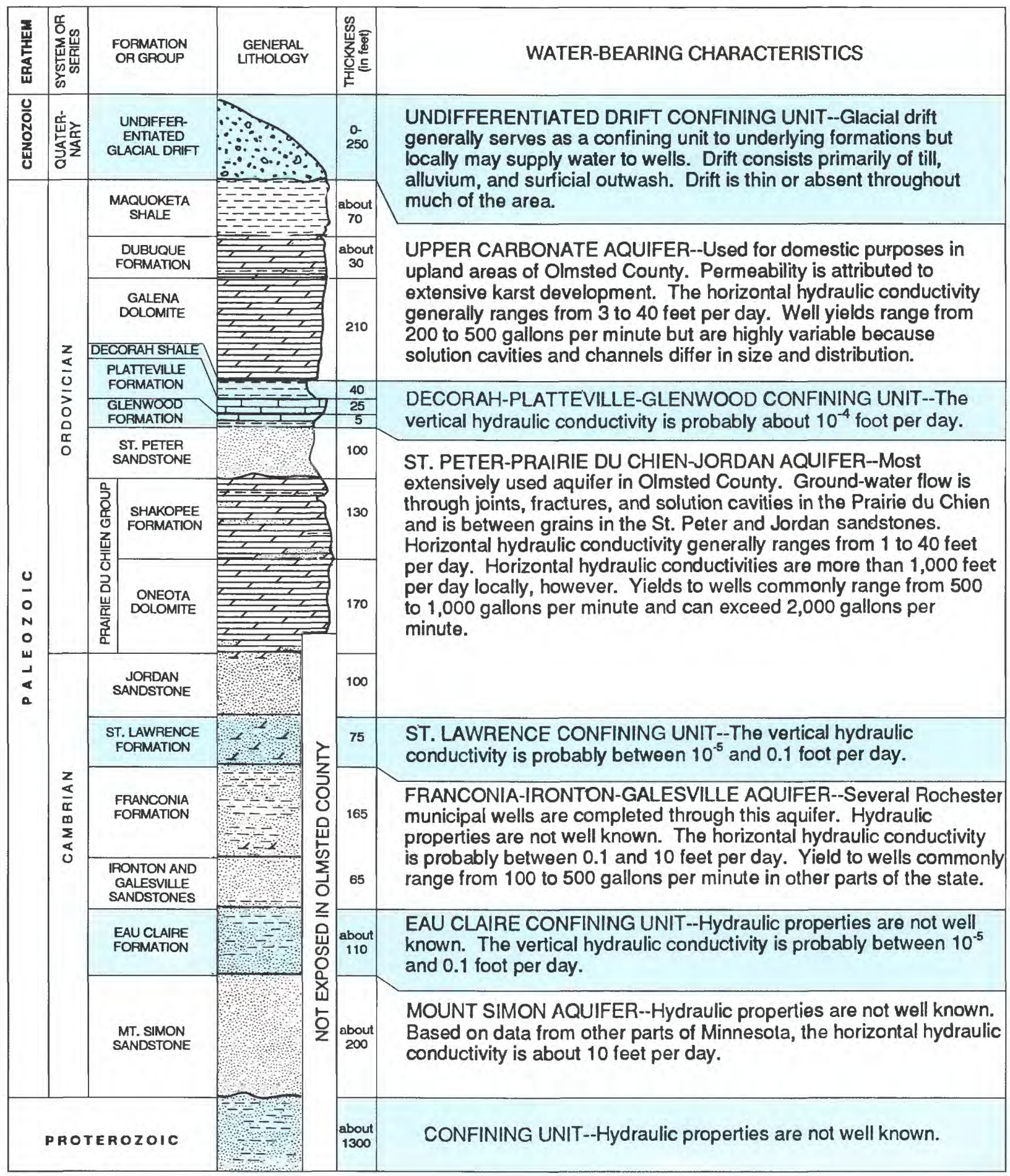

\section{EXPLANATION OF GENERAL LITHOLOGY}

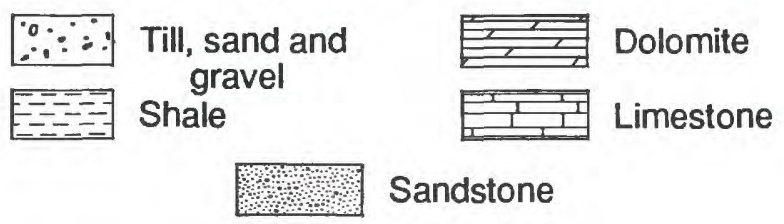

Figure 3. Generalized hydrogeologic column of regional aquifers and confining units. (Geology modified from N.H. Balaban, 1988.) 


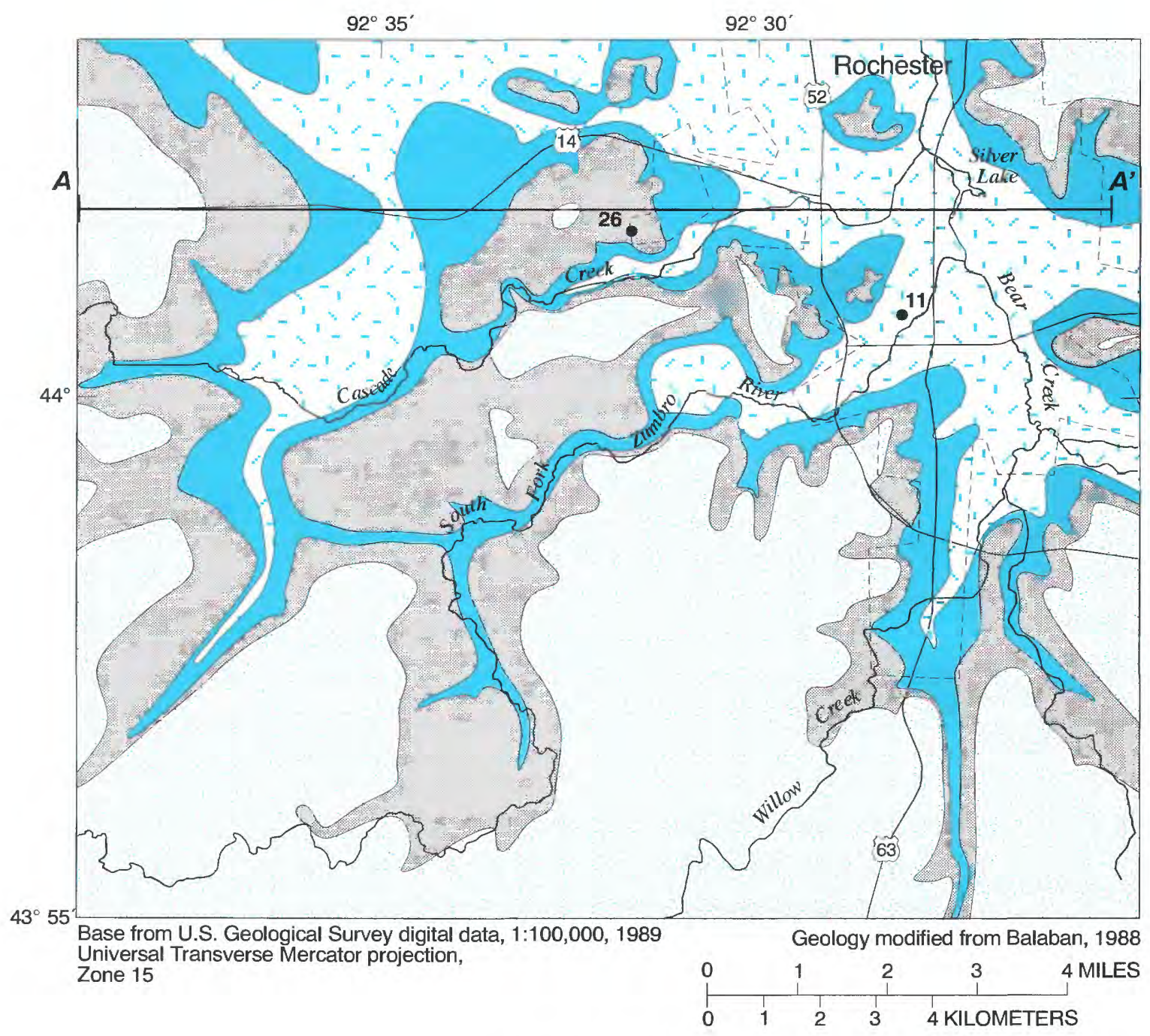

EXPLANATION

Bedrock hydrogeologic units:

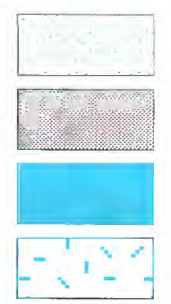

Galena Dolomite - part of the upper carbonate aquifer

Decorah-Platteville-Glenwood confining unit

St. Peter Sandstone (aquifer)

Prairie du Chien Group (aquifer)

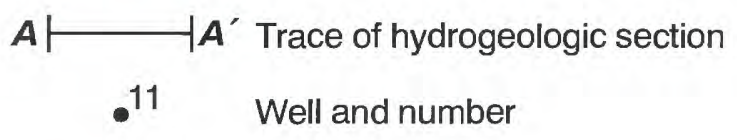

Figure 4. Bedrock hydrogeology.

to $1,000 \mathrm{ft}^{2} / \mathrm{d}$ (Delin, 1990). Data on anisotropy of the formation are lacking.

The St. Peter-Prairie du Chien-Jordan aquifer is unconfined along the South Fork Zumbro River valley, but the overlying Decorah-Platteville-Glenwood confining unit is present elsewhere (figs. 4 and 5). The confining unit is composed of shale, shaley dolomite and limestone, and dolomitic limestone. Average thickness of the confining 


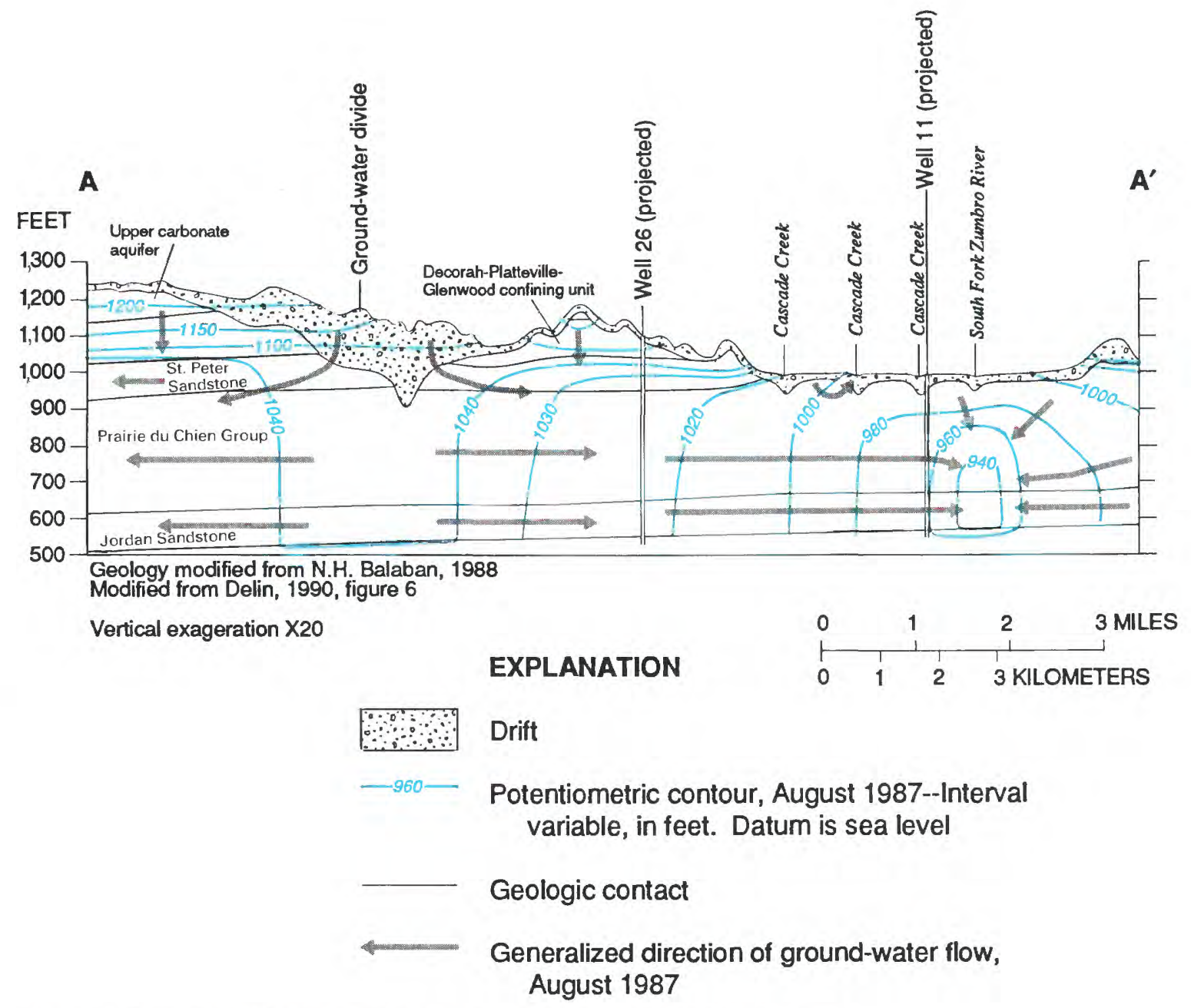

Figure 5. Generalized hydrogeologic section $A-A^{\prime}$ through the study area.

unit is about $70 \mathrm{ft}$ (Balaban, 1988), and its vertical hydraulic conductivity is probably $10^{-4}$ to $10^{-5} \mathrm{ft} / \mathrm{d}$ based on analyses by Delin (1990). The St. Peter-Prairie du Chien-Jordan aquifer is underlain by the St. Lawrence confining unit. This confining unit consists of dolomitic siltstone and is about $75 \mathrm{ft}$ thick in the area. The unit's vertical hydraulic conductivity is probably $10^{-3}$ to $10^{-5} \mathrm{ft} / \mathrm{d}$ based on analyses by Delin (1990).

Ground-water flow in the St. Peter-Prairie du ChienJordan aquifer is from a ground-water divide, located west, south, and east of Rochester, toward the South Fork Zumbro River (figs. 6 and 7). Horizontal ground-water flow predominates in the aquifer. A cone of depression is present in the potentiometric surface of the aquifer during summer months (fig. 6). The cone is centered approximately at the confluence of the South Fork Zumbro River and Bear Creek (fig. 6) and forms because of pumping from high-capacity wells in the area. Cones of depression are not evident in the potentiometric surface during winter months (fig. 7). The horizontal hydraulic gradient near Rochester is about 0.014 foot per foot $(\mathrm{ft} / \mathrm{ft})$ during the summer as compared with $0.004 \mathrm{ft} / \mathrm{ft}$ during the winter. Hydraulic-head data from wells suggest that vertical-head differences across the 500 -ft-thick aquifer are generally less than about $5 \mathrm{ft}$ downward (Delin, 1990). Heads generally increase with depth near streams in the area, however, and flow near streams is upward.

Recharge to the St. Peter-Prairie du Chien-Jordan aquifer occurs in several generalized zones in the area (Delin, 1990). Recharge to the aquifer occurs as leakage through the Decorah-Platteville-Glenwood confining unit, where it is present, at a rate of about 0.4 inches per year (in./yr). Where the Decorah-Platteville-Glenwood confining unit is absent, recharge occurs as infiltration from precipitation at a rate of about $5 \mathrm{in} . / \mathrm{yr}$. In the city of Rochester, where storm water runoff (potential recharge water) is diverted to sewers, recharge is likely less than in other areas where the Decorah-Platteville-Glenwood confining unit is absent. Recharge rates in Rochester are about $4.5 \mathrm{in} . / \mathrm{yr}$. Recharge in the area is greatest along the edge of the Decorah-Platteville-Glenwood confining unit because of the influx of water from springs at the base of the overlying 


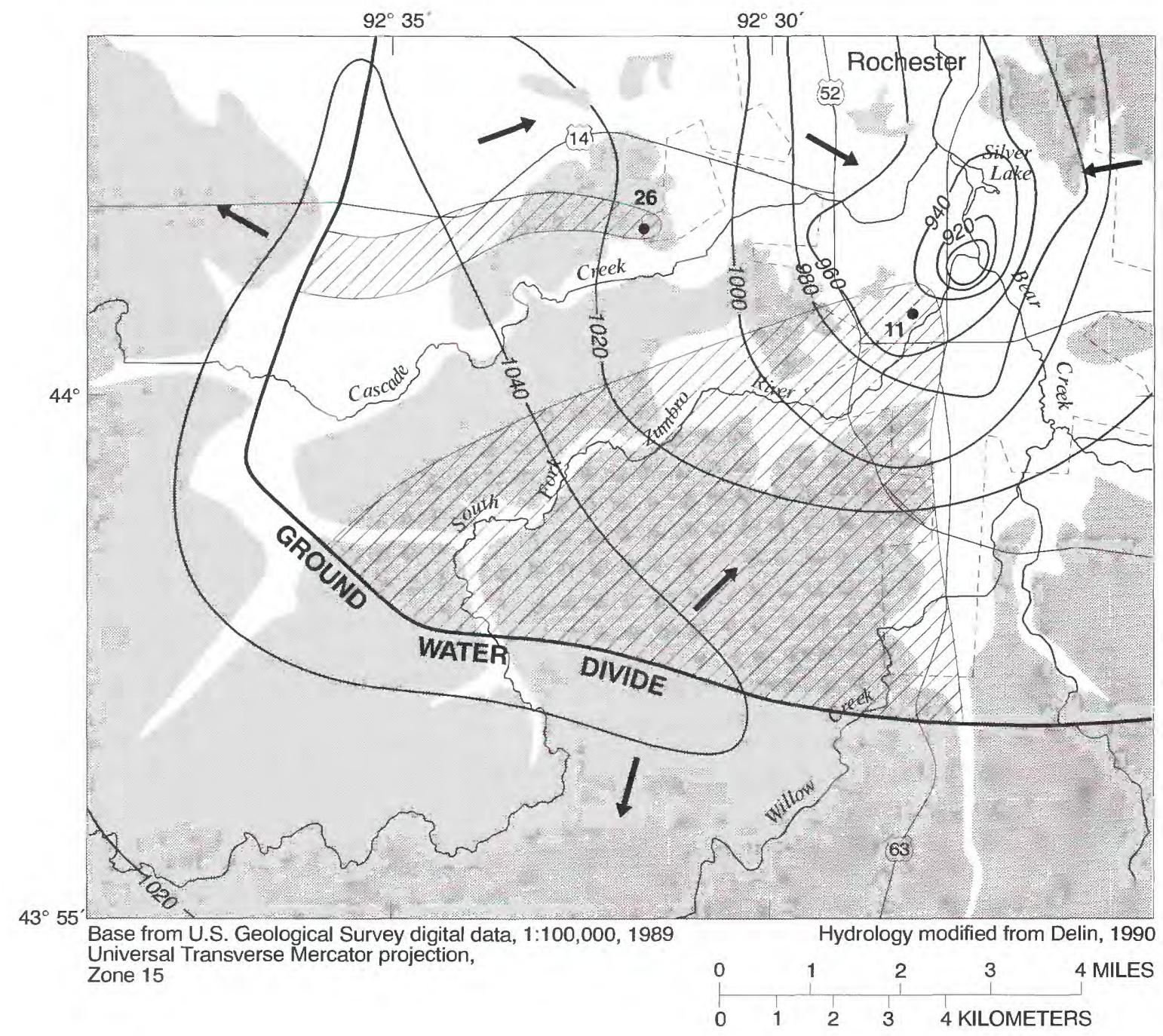

EXPLANATION

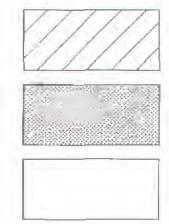

Zone of contribution

Decorah-Platteville-Glenwood confining unit

Prairie du Chien Group

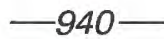

Potentiometric contour, August 1987--Contour interval 20 feet. Datum is sea level

$\longrightarrow \quad$ Direction of ground-water flow

-11 Well and number

Figure 6. Zones of contribution based on hydrogeologic mapping, high-gradient conditions.

upper carbonate aquifer. Recharge rates of about $13 \mathrm{in./yr}$ are likely in these areas (Delin, 1990).

Approximately 4.3 billion gallons of ground water was withdrawn from high-capacity wells in the Rochester area during 1986 (Douglas Rovang, Rochester Public Util- ities, written commun., 1987; and Minnesota Department of Natural Resources Water-Use Database). About 87 percent of this total is withdrawn from the St. PeterPrairie du Chien-Jordan aquifer. Figure 8 shows the location of high-capacity wells (withdrawals greater than about 


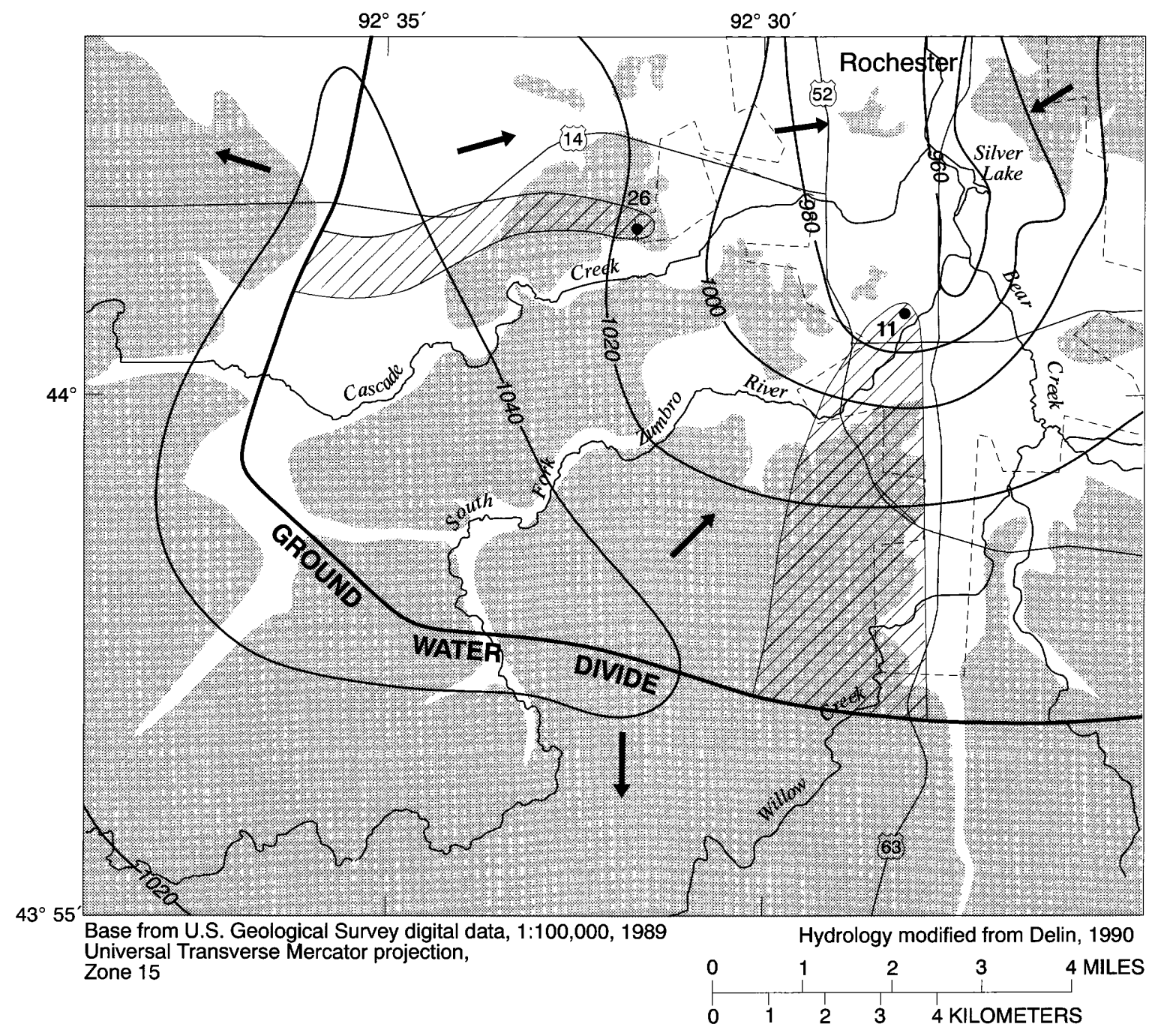

\section{EXPLANATION}

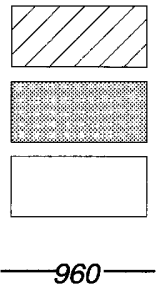

Zone of contribution

Decorah-Platteville-Glenwood confining unit

Prairie du Chien Group

Potentiometric contour, January 1988--Contour interval 20 feet. Datum is sea level

$\longrightarrow \quad$ Direction of ground-water flow

-11 Well and number

Figure 7. Zones of contribution based on hydrogeologic mapping, low-gradient conditions.

$200 \mathrm{gal} / \mathrm{min}$ ) completed in the St. Peter-Prairie du ChienJordan aquifer in the Rochester area. Withdrawals are greatest during summer months. For example, during the period of record (1977-88), municipal withdrawals from June through October averaged 1.3 times the average withdrawals from November through May (Douglas Rovang, Rochester Public Utilities, written commun., 1987). Consequently, water levels in the St. Peter-Prairie du Chien-Jordan aquifer commonly decline from 5 to $20 \mathrm{ft}$ each summer in the Rochester area (Delin, 1990). Summer 


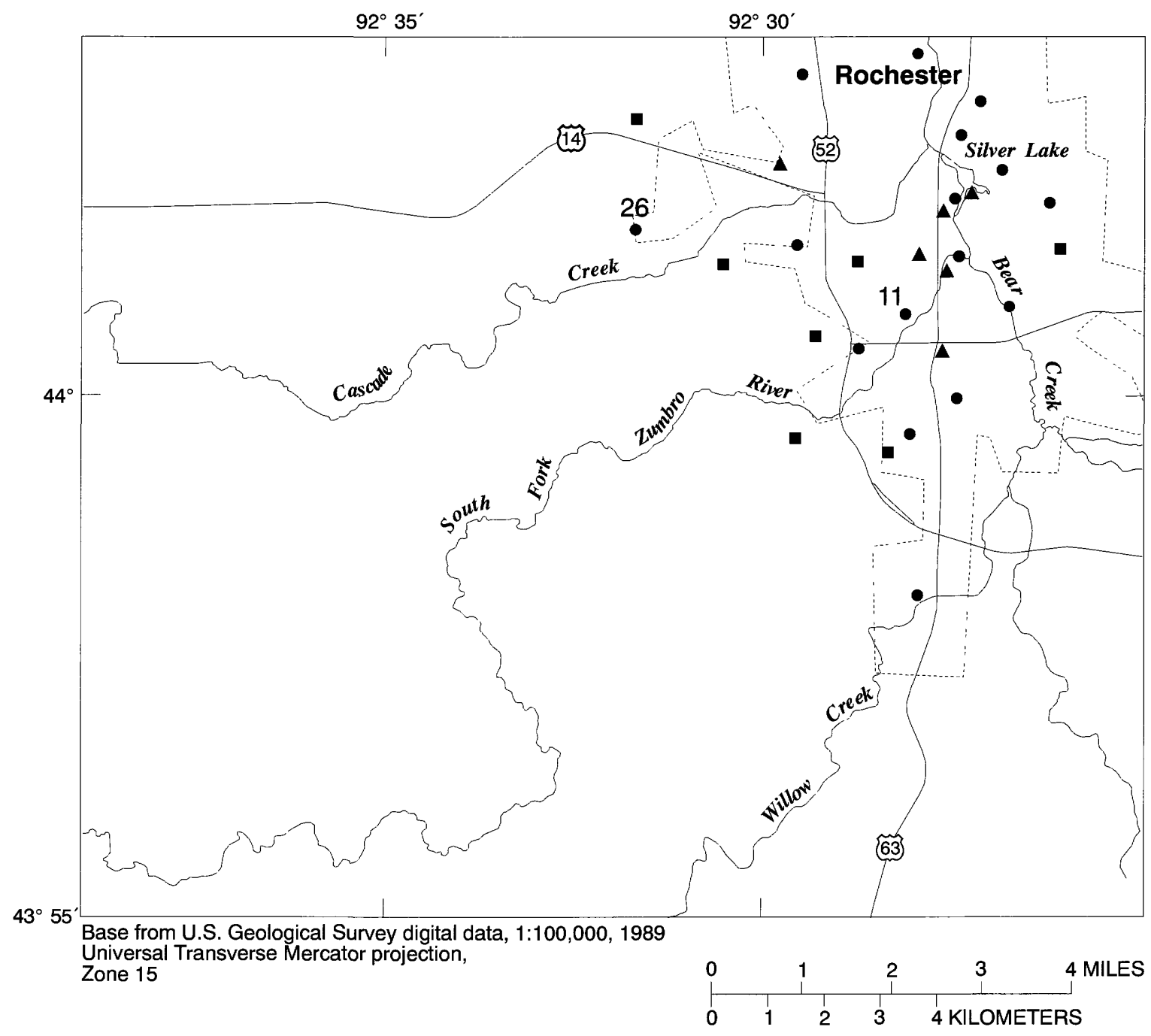

EXPLANATION

-11 Rochester municipal well and number

- Industrial well

- Other high-capacity well (discharge exceeds 200 gallons per minute)

Figure 8. Location of high-capacity wells in the study area.

declines outside the city of Rochester generally range from 1 to $4 \mathrm{ft}$ (Delin, 1990).

Stream-discharge measurements show that most stream reaches in the area gain water from the ground-water system (Delin, 1990). One reach of the South Fork Zumbro River near Rochester well number 11, however, lost streamflow during two separate stream-gaging periods. Analyses of dissolved radon gas concentrations in streamwater show that a $600-\mathrm{ft}$ section of this reach lost about 1.2 cubic feet per second $\left(\mathrm{ft}^{3} / \mathrm{s}\right)$ to the ground-water reservoir during July 1988 (Delin, 1990). Pumping of ground-water from nearby high-capacity wells is the likely cause of this reversal in flow.

\section{METHODS OF STUDY}

Methods outlined by the EPA (U.S. Environmental Protection Agency, 1987) were used to delineate recharge 
Table 1. Data requirements for the zone-delineation methods

$\left[b\right.$, saturated thickness of aquifer; $D$, drawdown; $h$, hydraulic head; $i$, regional hydraulic gradient; $K \& K_{l}$, horizontal and vertical hydraulic conductivity; $n$, porosity; $Q$, well discharge; $W$, areal recharge rate; $S$, storage coefficient; $t_{p}$, time since pumping began]

\begin{tabular}{|c|c|}
\hline Method & Information requirements \\
\hline I. Hydrogeologic mapping. & $\begin{array}{l}\text { Contour map of regional potentiometric surface, map of } \\
\text { surface-water bodies, knowledge of confining beds, knowl- } \\
\text { edge of aquifer connection to surface-water bodies. }\end{array}$ \\
\hline II. Numerical modeling ........ & $\begin{array}{l}Q \text { (all wells), } K, K_{v} \text {, anisotropy, } b, n, h, W \text {, river stage, } \\
\text { riverbed conductance, hydrologic boundary conditions. }\end{array}$ \\
\hline 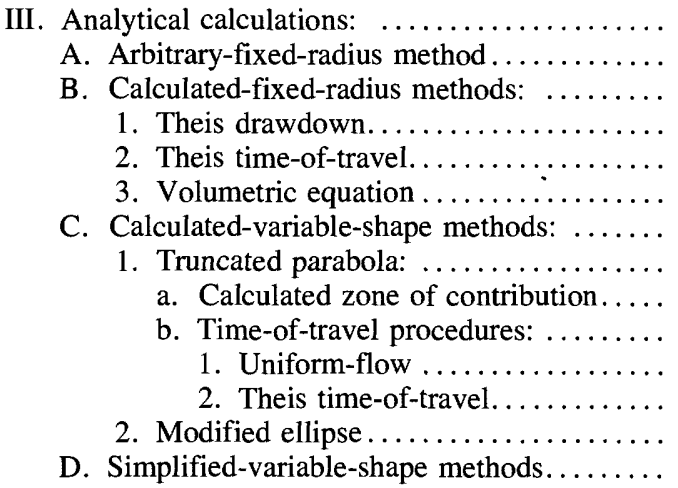 & $\begin{array}{l}Q, K, b, i \\
K, n, i . \\
Q, K, b, S, n, t_{p} \\
Q, K, b, n, i \\
\text { Same as above, depending on method selected. }\end{array}$ \\
\hline
\end{tabular}

areas surrounding selected wells in the Rochester area. Two types of recharge areas were delineated: zones of contribution and zones of transport.

Zones of contribution are delineated by hydrogeologic mapping or numerical modeling. The accuracy by which zones of contribution are determined by the hydrogeologic-mapping method will differ according to the experience of the water manager or hydrologist making the analysis and the amount of information available. Numerical models have the potential to produce the most accurate zone boundaries by incorporating changes in the hydrologic factors of the aquifer over space and time.

Zones of transport can be delineated by means of analytical models (calculations) or numerical ground-waterflow/transport models. Analytical calculations are generally easier but less accurate methods of delineating these zones. Analytical calculations used to delineate zones of transport (U.S. Environmental Protection Agency, 1987) include (1) the arbitrary fixed-radius method, (2) calculated fixedradius methods (Theis drawdown, Theis time-of-travel, and volumetric equation), (3) calculated variable-shape methods (calculated zone of contribution and time-of-travel), and (4) the simplified variable-shape method. The fixed-radius methods produce circular zones, whereas the variable-shape methods produce elongated zones that incorporate an assumed uniform-flow gradient in the aquifer.

It is important to recognize the transient nature of zones of contribution and transport. Zone boundaries are not stationary under conditions of changing pumping rates, climate, or land use. An increase or decrease in the pumping rates of nearby wells, for example, may change the shape and location of recharge areas for a given well.
Fluctuations in pumping rates are of particular concern in areas where wells are located in close proximity to each other. The analytical and numerical-modeling methods, however, assume steady-state conditions. Therefore, the recharge areas computed for wells near other high-capacity wells are inherently less accurate than recharge areas computed for wells relatively distant from other highcapacity wells.

Delineation of recharge areas for a well requires accurate estimates of the hydrologic factors governing ground-water flow. The most important hydrologic factors relevant to delineating recharge areas in this study are horizontal hydraulic conductivity, porosity, saturated thickness, and well discharge. Most of the methods used to delineate recharge areas require knowledge of these hydrologic factors. Areal anisotropy is another important hydrologic factor in karst terrain; however, only the numericalmodeling method can account for anisotropy. Information on the regional hydraulic gradient is required for the variable-shape methods. Other hydrologic factors relevant to delineating recharge areas include vertical hydraulic conductivity, storage coefficient, areal recharge rate, and drawdown in the well. Data requirements for each zonedelineation method are summarized in table 1.

The sensitivity of the hydrologic factors pertinent to each method is discussed later in the report. The theory for each zone-delineation method is described in the following paragraphs.

\section{Hydrogeologic Mapping}

The hydrogeologic-mapping method is one of the easiest methods identified by the EPA to delineate recharge 
areas. A potentiometric-surface map for the aquifer in which the well is completed is the primary requirement for this method.

Zones of contribution delineated by use of the hydrogeologic-mapping method can be divided into three parts. The primary part of the zone of contribution is delineated by drawing dividing streamlines (fig. 1) separating areas that contribute flow to the well from areas that do not contribute flow to the well. The dividing streamlines are drawn from a stagnation point downgradient from the well to the regional ground-water divide. The area bounded by the dividing streamlines and the ground-water divide is the zone of contribution for that well. The location of the stagnation point can usually be identified only approximately from the potentiometric-surface map, unless detailed water-level data are available near the well. Analytical calculations may also be used, however, to estimate the location of the stagnation point.

The second part of the zone of contribution delineated by use of the hydrogeologic-mapping method includes areas where a confining unit partially covers the zone of contribution for that well. Water and contaminants from an overlying aquifer and land surface could potentially seep over the edge of this confining unit into the aquifer below; thus, any part of the overlying landscape that delivers water to the edge of the confining unit should be considered part of the zone of contribution for that well.

A third part of the zone of contribution is taken into account if a well induces infiltration of water from a nearby stream. Under these conditions, the entire watershed of that stream above the well is part of the zone of contribution for that well.

\section{Analytical Calculations}

Analytical methods for estimating recharge areas are useful for preliminary analyses or feasibility studies because they require only pencil and paper and can be solved quickly. Because not all analytical methods may be appropriate for a particular aquifer, however, the suitability of a method for a particular aquifer system must be considered before it is used. Often the assumptions upon which the method is based are not met by the aquifer system.

Fixed-radius methods are easy to use but are based on assumptions that are rarely, if ever, met in the field. For example, all fixed-radius methods assume radial flow and therefore neglect regional flow. In real aquifer systems, however, the assumption of radial flow is always violated at some distance from every well. On the other hand, at some point near the well, regional potentiometric-surface gradients are overwhelmed by the effects of pumping, and ground-water flow becomes approximately radial. Consequently, the fixed-radius methods may be applicable for short travel times and distances near the well. Exactly when these methods could be useful for an aquifer system depends on the specifics of that system.

Variable-shape methods are a more accurate alternative to fixed-radius methods but require greater time and expertise to construct. The variable-shape methods are also based on many assumptions that are not met in the field.

\section{Fixed-Radius Methods}

Circular zones of transport may be constructed by use of several simple methods, if adequate hydrogeologic information is available. Note that calculations used to delineate circular zones are generally valid only in areas with a relatively low regional hydraulic gradient. When a regional hydraulic gradient is imposed near a well, a circle cannot accurately represent a zone of transport. In such a case, the zone shifts in the upgradient direction and variable-shape methods are more accurate. Four methods for calculating circular zones of transport are discussed below: arbitrary fixed radius, Theis drawdown, Theis time-of-travel, and volumetric equation.

\section{Arbitrary fixed radius}

The simplest method of delineating a zone of transport is to identify a circular area with an arbitrary fixed radius (U.S. Environmental Protection Agency, 1987), commonly from several hundred to several thousand feet, around a well. Presumably, some professional judgment could be applied when choosing a radius, and perhaps some very simple calculations could be done to designate a reasonable choice for a radius or set of radii. Obviously, the more calculations that go into choosing a given radius the less arbitrary it becomes. This method is not discussed further in this report because calculations are not required.

\section{Theis drawdown}

A fixed-radius recharge zone can be calculated from the Theis equation and drawdown-related data (U.S. Environmental Protection Agency, 1987). The assumption behind the method is that the land-surface area within the cone of depression for a well (fig. 1) could deliver contaminants to the well. Thus, a zone of influence for a well is computed by use of this method. The estimated radius of a zone of influence is computed by solving the Theis equation (Freeze and Cherry, 1979, p. 317) for the value of the radius

and

$$
D=[Q /(4 \pi T)] W(u)
$$

$$
u=\left[r^{2} S\right] /\left[4 T t_{p}\right]
$$

where

$D$ is drawdown $(l)$,

$Q$ is well discharge $\left(l^{3} / t\right)$,

$\pi$ is 3.1416 (dimensionless),

$T$ is transmissivity $\left(l^{2} / t\right)$, 
$W(u)$ is the well function (dimensionless),

$r$ is radial distance from the well $(l)$,

$S$ is storage coefficient (dimensionless), and

$t_{p}$ is time since pumping began $(t)$.

This equation can be used to predict drawdown for any distance from the well. Any zone of finite radius calculated by this equation is encompassed by a circle of equal drawdown.

Ideally, a zone of influence is bounded by a line along which drawdown is zero. In practice, however, it may be necessary to select a limiting drawdown greater than zero if the area computed for the zone of influence based on available hydraulic data is unreasonably large. The size of the zone of influence, however, is sensitive to the value of the limiting drawdown. An increase in the value for the limiting drawdown $(D)$ will result in a decrease in the area for the zone of influence. This situation reveals an inherent problem with the Theis drawdown method because criteria for selection of a limiting drawdown other than zero are unclear and arbitrary.

The Theis equation is based on the assumption that the production well fully penetrates a confined aquifer of infinite areal extent and that the pumped water originates solely from aquifer compression and water expansion. It is unlikely, however, that production wells receive water from this mechanism alone. It is more likely that wells also receive water from the capture of ground-water recharge because the Theis equation predicts an ever-widening cone of depression as the well is pumped. It is important to realize that the radius of influence created by pumping over time (for example, 1,5 , or 10 years) is not the same as the distance traveled by ground water in the aquifer over that time interval. Although the Theis drawdown method is used to delineate a zone of influence rather than a zone of transport for a well, the method is included in this report with the other fixed-radius methods for comparison.

It is emphasized that the Theis-drawdown method is based on the false premise that drawdown is the critical variable controlling the zone of transport for a well. Instead, the movement of ground water toward the well is determined by the distribution of hydraulic gradients in the aquifer system. Drawdown does enter into the analysis indirectly in the sense that when the drawdown distribution associated with a well is superimposed on the existing head distribution, gradients will change and some water will be diverted to the well. The drawdown distribution by itself, however, does not provide any information on the size or shape of the zone of transport.

\section{Theis time-of-travel}

The Theis time-of-travel method (U.S. Environmental Protection Agency, 1987) produces a fixed-radius zone of transport based on hydraulic gradients approximated from Theis equations 1 and 2. Time-of-travel estimates for average pore-water flow are based upon Darcy's law, modified by the porosity of the aquifer (Strack, 1989, p. 6-9)

$$
d s / d t=v=q / n=-(K d h / d s) / n,
$$

where

$s$ is distance along a flow line $(l)$,

$t$ is time,

$v$ is average pore-water velocity along a flow line, $d s / d t(l / t)$,

$q$ is specific discharge, or Darcy flux $(l / t)$,

$n$ is porosity (dimensionless),

$K$ is horizontal hydraulic conductivity $(l / t)$,

$h$ is hydraulic head $(l)$, and

$d h / d s$ is hydraulic gradient (dimensionless).

As an approximation, discrete quantities can be substituted for the differentials $d h, d s$, and $d t$ (that is, let $d s=\left(s_{2}-s_{1}\right)$, $d t=\left(t_{2}-t_{1}\right)$, and $\left.d h=\left(h_{2}-h_{1}\right)\right)$. If flow lines are radial, the Theis equation can provide an estimate of $\left(h_{2}-h_{1}\right)$ over the distance $\left(s_{2}-s_{1}\right)$, and equation 3 may then be solved algebraically for the travel time $\left(t_{2}-t_{1}\right)$ over that distance. Flow lines are divided into segments and travel times are summed for each segment to the desired travel time $(1,5$, or 10 years in this report) to find the total distance traveled (U.S. Environmental Protection Agency, 1987).

A static potentiometric surface is assumed in the time-of-travel calculation described above. The application of the Theis equation to estimate travel times is not consistent with the theory upon which the equation is based, however, because the equation describes a transient configuration of the potentiometric surface. To calculate a drawdown curve (that is, drawdown as a function of radial distance from the well), a value of time (since pumping began) is specified. After about 1 year of pumping, the drawdown calculated by use of the Theis equation changes little, and travel time estimates are independent of the values of time used for pumping. Thus, the 1-year drawdown curve could be used to estimate the radii of the zone-of-transport boundaries. Because the gradient of the 10-year drawdown curve is the greatest and results in the greatest distance traveled, this curve was used to estimate the radii of the zone-of-transport boundaries.

\section{Volumetric equation}

The volumetric-equation method (U.S. Environmental Protection Agency, 1987) produces a fixed-radius zone of transport based on the volume of aquifer supplying water to a well being pumped at a specified rate for a given time period. For a well pumping at rate $Q$ over time period $\left(t_{t}\right)$, the total volume of water pumped is $Q t_{t}$. For a cylindrical aquifer volume of radius $(r)$, height $(b)$, and porosity $(n)$ the total volume of water contained therein is $n b \pi r^{2}$. Equating these two volumes of water and solving for $r$ yields

$$
r=\left[\left(Q t_{t}\right) /(b n \pi)\right]^{0.5},
$$


where

$r$ is radial distance $(l)$,

$Q$ is well discharge $\left(l^{3} / t\right)$,

$\pi$ is 3.1416 (dimensionless),

$t_{t}$ is time of travel, or time of pumping $(t)$,

$b$ is aquifer thickness $(l)$, and

$n$ is porosity (dimensionless).

This equation can be derived alternatively by integration of equation 3 with the expression for $d h / d s$ supplied by differentiation of the Thiem equation (see Strack, 1989) with respect to $r$. In this situation, all flow is assumed to be radial, and hence the distance along a flow line $s$ in equation 3 is equivalent to the cylinder radius $(r)$ in equation 4 . For unconfined conditions, results from equation 4 are only approximate; however, if head at the well screen is substituted for aquifer thickness $(b)$, equation 4 will produce a conservative (that is, larger than theoretically required) estimate of the zone-of-transport radius.

\section{Variable-Shape Methods}

A variable-shape method (U.S. Environmental Protection Agency, 1987) for delineating a zone of transport is one that superposes the effect of a uniform-flow gradient on that of a well being pumped. The shape of the zone varies in response to the strength of the regional hydraulic gradient. Two types of variable-shape methods-truncated parabola and modified ellipse-are discussed.

\section{Truncated parabola}

Calculation of a variable-shape zone of transport by use of this method involves two steps. The first step is to calculate a zone of contribution (parabola) based on some simplifying assumptions. This zone of contribution forms the lateral and downgradient boundaries of the zone of transport relative to the direction of the regional hydraulic gradient. The second step is to use travel times to calculate the distance traveled by the pore water within the zone of contribution and thereby to form the upgradient boundary of the zone of transport. The zone of contribution is simply truncated by a line drawn perpendicular to the regional flow at that point, using either uniform-flow or Theis time-oftravel procedures (U.S. Environmental Protection Agency, 1987).

The zone-of-contribution boundary for the truncatedparabola method can be calculated by use of a set of standard equations (Todd, 1980, p. 121). If a well is placed at the origin of a coordinate system oriented such that the $\mathrm{x}$-axis is parallel to the direction of uniform flow, dividing streamlines form and meet at a stagnation point located $X_{L} \mathrm{ft}$ downgradient from the well (fig. 1).

The dividing streamlines become nearly parallel to the $\mathrm{x}$-axis in the upgradient direction and approach asymptotes at locations $\pm Y_{L}$ (fig. 1). These dividing streamlines can be extended to a ground-water divide upgradient from the wells and can encompass large areas. The zone of contribution for that well is the strip of aquifer lying between these dividing streamlines and the ground-water divide (U.S. Environmental Protection Agency, 1987). The locations of the stagnation point $\left(X_{L}\right)$ and the asymptotes $\left( \pm Y_{L}\right)$ are computed by use of the following equations

where

$$
\begin{gathered}
X_{L}=w /(2 \pi) \\
Y_{L}=w / 2,
\end{gathered}
$$

$w=Q /(-K b i)=Q / Q_{x}$ is limiting width of aquifer from which the well captures flow $(l)$,

$Q$ is well discharge $\left(l^{3} / t\right)$,

$K$ is horizontal hydraulic conductivity $(l / t)$,

$b$ is aquifer thickness $(l)$,

$i$ is hydraulic gradient of uniform flow (dimensionless),

$\pi$ is 3.1416 (dimensionless), and $\mathrm{Q}_{\mathrm{x}}=-K b i$ is strength of the uniform flow field $\left(l^{2} / t\right)$.

The equation for the dividing streamlines is

$$
x=y /\left[\tan \left(y / X_{L}\right)\right] \text {. }
$$

Computation of either the location of the stagnation point $\left(X_{L}\right)$ or the limiting width of the aquifer $(w)$ is sufficient to delineate the zone of contribution by this method. Todd (1980, p. 121-123) derives equations 5-7 for confined conditions. Part of the terminology in equations 5-7 comes from Strack (1989, p. 228-231), who derives a more encompassing set of equations that are also applicable to Dupuit-Forchheimer unconfined flow to a well.

Results of equations 5-7 depend on the maximum width $(w)$ of the part of the aquifer from which the well captures flow. The width equals the ratio of the well discharge $(Q)$ to the strength of the uniform-flow field $\left(Q_{x}\right)$. The larger the magnitude of the uniform-flow field (steeper regional hydraulic gradient) relative to the well discharge, the narrower the recharge area upgradient from the well. The stagnation point $\left(X_{L}\right)$ will also be closer to the well. Alternatively, if the magnitude of the uniform-flow field is small (flat regional hydraulic gradient) relative to the well discharge, the zone of contribution can be extremely wide. In the limiting case of no uniform flow $\left(Q_{x}=0\right)$, the zone is infinitely wide and covers the entire $x-y$ plane.

In the application of equations 5-7, the most difficult parameter to estimate is the regional hydraulic gradient $(i)$. Both its magnitude and direction must be determined, preferably in the field. It is important to measure the background hydraulic gradient when the aquifer is not under the influence of pumping from the well being considered. If the well were pumped, the hydraulic gradient could be overestimated; the calculated zone of contribution would be narrower than the actual zone of contribution. The magnitude and direction of the hydraulic gradient can be estimated 
from a potentiometric-surface map for an aquifer. Seasonal changes in aquifer recharge and discharge also shift the value of the hydraulic gradient. The hydraulic gradient typically reaches its lowest value during winter because pumping of water and natural flux through the ground-water system are least during that season. Hydraulic gradients are rarely uniform, however, particularly near streams.

Equation 5 shows that the location of the stagnation point $\left(X_{L}\right)$ is directly proportional to well discharge $(Q)$ and inversely proportional to the horizontal hydraulic conductivity $(K)$ and hydraulic gradient $(i)$; hence, a change in well discharge results in the same percentage change in the location of the stagnation point. Conversely, changes in horizontal hydraulic conductivity or hydraulic gradient produce changes of reciprocal magnitude in the location of the stagnation point; therefore, a given percentage decrease in either horizontal hydraulic conductivity or hydraulic gradient will cause a greater percentage increase in the value of the stagnation point. It is intuitively clear that decreases in well discharge and increases in hydraulic gradient tend to decrease the value of the stagnation point and narrow the zone of contribution. Explanation for the inverse effect of horizontal hydraulic conductivity, however, is less obvious. A low hydraulic-conductivity value implies that the magnitude of the uniform-flow field is relatively low for the measured hydraulic gradient. Hence, a well discharging at a given rate must capture flow from a proportionally wider strip of the aquifer than if the aquifer had a higher horizontal hydraulic conductivity and a larger hydraulic gradient.

The uniform-flow procedure (U.S. Environmental Protection Agency, 1987) for truncating the calculated zone of contribution is based on the assumption that the distance a particle of water travels over a given period of time is primarily a function of the hydraulic gradient $(i)$. The hydraulic effects of the pumped well are ignored. The same hydraulic-gradient value used in calculating the zone-ofcontribution parabola above may be used here. Assuming the hydraulic gradient is constant in the vicinity of the well, one may solve equation 3 algebraically to obtain

$$
x=-t_{t} K i / n,
$$

where

$x$ is distance traveled $(l)$,

$t_{t}$ is time of travel $(1,5$, or 10 years in this report) $(t)$,

$K$ is horizontal hydraulic conductivity $(l / t)$,

$i$ is hydraulic gradient of uniform flow (dimensionless; $i<0$ when measured in the direction of flow), and

$n$ is porosity (dimensionless).

The calculated distance $(x)$ traveled by a water particle for a given travel time is measured upgradient from the well, and the zone-of-contribution parabola calculated in the previous section is truncated at that point. The zone of transport is then complete; the lateral and downgradient parts of the zone boundary are from the calculated zone of contribution, and the upgradient part of the zone boundary is from the uniform-flow procedure.

The sensitivity of the uniform-flow procedure to changes in horizontal hydraulic conductivity and hydraulic gradient can be computed directly from equation 8 . Equation 8 shows that the distance is directly proportional to the horizontal hydraulic conductivity and the hydraulic gradient and inversely proportional to the porosity.

In the Theis time-of-travel procedure (U.S. Environmental Protection Agency, 1987) for truncating the calculated zone of contribution, the uniform-flow gradient is ignored and only that gradient caused by pumping the well is considered. In other words, the radii for the circular zones of transport, based on a Theis time-of-travel calculation, can be used as the upgradient distance at which to truncate the calculated zone of contribution. Because the effect of increasing uniform flow upgradient to the well is ignored in the Theis time-of-travel procedure, the distance to the upgradient boundary of the zone of transport is necessarily underestimated by the method. For further discussion of the theory and application of this method refer to the earlier description of the Theis time-of-travel method for delineating a zone of transport.

For the truncated-parabola method of delineating a zone of transport to be practical, the value of the limiting width of aquifer ( $w$, eqs 5 and 6) must be the same size as, or smaller than, the distances calculated by the time-oftravel procedures used to determine the upgradient boundary.

\section{Modified ellipse}

As discussed above, the truncated-parabola method produces zones of transport that likely overestimate the recharge area downgradient from a well and underestimate the recharge area upgradient from a well. Consequently, an alternative zone-delineation method was developed that would apply to any range of well discharge and hydraulic gradient. This method is called the modified-ellipse method.

The modified-ellipse method is based on the assumption of steady-state flow in a confined aquifer with a production well at the origin of an $x-y$ coordinate system in which flow is parallel to the $\mathrm{x}$-axis. In such a system, only the two streamlines along the $\mathrm{x}$-axis are straight; one streamline approaches the well from directly upgradient and the other starts at the stagnation point and approaches the well from the downgradient side. Strack (1989, p. 22, 228) derives an expression for hydraulic head $(h)$ as a function of position for a well in a uniform-flow field. This expression may be differentiated along the $\mathrm{x}$-axis to provide a value for $d h / d x$, which may be substituted for $d h / d s$ in equation 3 . 
Integration, with respect to time, then provides travel time $\left(t_{t}\right)$ as a function of distance traveled along the $\mathrm{x}$-axis

$$
t_{t}=B(A x i-\ln (1+A x i)) \text {, }
$$

where

$B$ is $-n /\left(A K i^{2}\right)(t)$,

$A$ is $K b 2 \pi / Q(1 / l)$,

$n$ is porosity (dimensionless),

$t_{t}$ is travel time $(t)$,

$K$ is horizontal hydraulic conductivity $(l / t)$,

$i$ is hydraulic gradient of uniform flow (dimensionless),

$b$ is aquifer thickness $(l)$, and

$Q$ is well discharge $\left(l^{3} / t\right)$.

For a given travel time, equation 9 can be used to find the distances that the two water particles travel along the two streamlines collinear with the $x$-axis. The starting positions $(X-$ and $X+)$ of these two water particles represent the points at which the zone-of-transport boundary crosses the $\mathrm{x}$-axis. The total aquifer volume that provides water to the well over a given length of time $(t)$ depends on the well discharge $(Q)$ and the porosity $(n)$. For horizontal flow in an aquifer of constant thickness, this aquifer volume may be represented by its area in the $x-y$ plane. In the absence of a uniform-flow field, this area is bounded by a circle, the radius of which may be computed by use of the volumetric-equation method. When a uniform-flow field is present, this area is the same, but its shape is stretched in the upgradient direction from the well. The shape approximates an ellipse, the boundary of which may be calculated given both its area ( $\pi r^{2}$, with $r$ from eq 4$)$ and its major axis (the distance between $X-$ and $X+$ ).

The advantage of the modified-ellipse method is that it makes smooth transitions from areas of high to low uniform-flow gradients. As the uniform-flow gradient approaches zero, the modified ellipse approaches a circle. As time approaches infinity, the modified ellipse approaches a shape similar to the truncated parabola. For unconfined conditions, the modified ellipse should provide a conservative estimate of the zone of transport, provided that the hydraulic head at the well is substituted for the aquifer thickness. The distance from the well to the upgradient boundary of the zone of transport $(X+)$ is the variable required by the modified-ellipse method that varies most under different hydrogeologic conditions. An analytical method similar to the modified ellipse is prescribed by Javandel and others (1984, p. 35-67). Bear (1979) gives the exact analytic solution for the boundary of the zone of transport, which is only approximated by the modified ellipse. Bear's solution, however, is difficult to calculate without a computer-implemented algorithm.

\section{Simplified variable shape}

If average or typical values for the hydrologic factors could be evaluated for a given region, then a set of generic zone-of-transport shapes or simplified variable shapes (U.S. Environmental Protection Agency, 1987), could be constructed by use of one or more of the above numericalmodeling or analytical methods. The size and shape of these generic zones of transport would be a function of the well discharge $(Q)$ and the regional hydraulic gradient $(i)$. The simplified-variable-shape method typically is not a separate method of zone delineation, but rather an application of one of the other methods to a range of possible values for well discharge and regional hydraulic gradient for an area. Any well in a region could, therefore, be assigned an appropriate zone from this set of generic zones if the well discharge and the hydraulic gradient in the area immediately surrounding the well were known.

\section{Numerical Modeling}

Numerical models are an alternative to analytical calculations for delineating recharge areas to wells. Numerical models can incorporate data that are representative of the complexities in a ground-water-flow system. Numerical models, for example, can incorporate local variations in aquifer hydraulic conductivity as well as ground-water discharge to and leakage from streams. In addition, the effects of nearby pumped wells on the recharge areas for a well can be evaluated with numerical models. Simulation of these hydrologic factors is generally beyond the capabilities of analytical calculations. Analytical calculations can be used to evaluate spatial variations in hydraulic gradient and the effects of aquifer boundaries such as streams (using the image-well theory) only in relatively simple hydrogeologic settings. Therefore, it is reasonable to assume that the model-computed recharge areas are more representative of actual conditions than are estimates based on analytical calculations.

A three-dimensional finite-difference ground-waterflow model, constructed and calibrated to steady-state conditions during a previous USGS study (Delin, 1990), was used in this investigation with a Fortran program (Pollock, 1989) to delineate recharge areas for the selected wells. The computer code by McDonald and Harbaugh (1988) was used to simulate ground-water flow. The model was designed to simulate steady-state, regional groundwater flow in the Rochester area. The model was not specifically designed for delineating recharge areas for wells in the area, however. Output from the model was used as input for a postprocessing Fortran program (Pollock, 1989) to delineate recharge areas for selected wells by tracking water particles within the simulated flow system.

The particle-tracking program (Pollock, 1989) uses a semianalytical particle-tracking scheme. The method is based on the assumption that each directional velocity component of a water particle varies linearly within a cell in its own coordinate direction. This assumption allows an 
analytical expression describing the flow path within each cell to be obtained. The particle is then tracked as it moves from cell to cell through the steady-state three-dimensional flow system.

The particle-tracking program was used by first specifying starting locations at the top of the aquifer, for hypothetical water particles throughout the simulated region. The particles were then tracked forward in time through the steady-state velocity field until they reached a boundary where flow was out of the system (such as a river) or until they entered a cell containing an internal sink (such as a well). All water particles entering a cell containing a well were assumed to discharge to these relatively strong sinks. The area encompassing the starting points of water particles traced to each well used in this investigation delineated the zone of contribution for that well. A zone of transport was delineated by encompassing the starting points of water particles traced to a given well for a specified travel time $(1,5$, or 10 years). Results from the ground-water-flow model/particle-tracking program are referred to as numerical-model results in this report. Implicit to the numerical model is the assumption that the computed recharge areas were based on steady-state contaminant movement by advection only; dispersive transport of solutes is not considered. Qualitatively, however, it is clear that the effects of dispersion would enlarge the recharge areas.

\section{DELINEATION OF RECHARGE AREAS}

Rochester municipal well numbers 11 and 26 were selected for application of the different methods for delineating recharge areas. These wells were selected primarily because they are located in different hydrogeologic settings. Rochester well 11 is about $700 \mathrm{ft}$ from the South Fork Zumbro River (fig. 6) in an area where the DecorahPlatteville-Glenwood confining unit is absent. In contrast, well 26 is more than 2,000 ft from Cascade Creek (fig. 6) in an area where the Decorah-Platteville-Glenwood confining unit is present. On the basis of model analyses (Delin, 1990), recharge to the St. Peter-Prairie du Chien-Jordan aquifer near well 11 is about an order of magnitude greater than near well 26. In addition, discharge from well 11 is about four times greater than the discharge from well 26 (table 2). Both wells are completed in the Prairie du Chien and Jordan parts of the St. Peter-Prairie du Chien-Jordan aquifer. The hydrologic factors of the area around each well (table 2) were computed from data collected by Delin (1990). Note that, although the Decorah-PlattevilleGlenwood confining unit is present near well 26 , the storage coefficient of 0.1 for this well indicates that the aquifer response to pumping is equivalent to that in an unconfined aquifer.
Table 2. Hydrologic factors for the areas around wells used in the recharge-area calculations

[STPR, St. Peter Sandstone; PDCN, Prairie du Chien Group; JRDN, Jordan Sandstone]

\begin{tabular}{|c|c|c|}
\hline $\begin{array}{l}\text { Hydrologic } \\
\text { Property }\end{array}$ & Well 11 & Well 26 \\
\hline $\begin{array}{l}\text { Average pumping rate } \\
\qquad(\mathrm{gal} / \mathrm{min}) \ldots \ldots \ldots\end{array}$ & 415 & 92 \\
\hline $\begin{array}{l}\text { Approximate recharge rate } \\
\quad \text { (in./yr) } \ldots \ldots \ldots \ldots \ldots \ldots\end{array}$ & 4.5 & .4 \\
\hline $\begin{array}{l}\text { Hydraulic gradient, } \\
\text { winter months }(\mathrm{ft} / \mathrm{ft}) \ldots\end{array}$ & .004 & .003 \\
\hline $\begin{array}{l}\text { Hydraulic gradient, } \\
\text { summer months }(\mathrm{ft} / \mathrm{ft}) .\end{array}$ & .014 & .004 \\
\hline $\begin{array}{l}\text { Storage coefficient } \\
\quad(\text { dimensionless }) \ldots \ldots \ldots \ldots \ldots\end{array}$ & .3 & .1 \\
\hline $\begin{array}{l}\text { Horizontal hydraulic } \\
\text { conductivity }(\mathrm{ft} / \mathrm{d}) \ldots \ldots \ldots \ldots\end{array}$ & 5.2 & 8.2 \\
\hline $\begin{array}{l}\text { Vertical hydraulic } \\
\text { conductivity }(\mathrm{ft} / \mathrm{d}) \ldots \ldots\end{array}$ & 1.0 & 1.0 \\
\hline $\begin{array}{l}\text { Horizontal anisotropy of } \\
\text { the STPR, PDCN, \& JRDN }{ }^{1} \text {. }\end{array}$ & $1: 1$ & $1: 1$ \\
\hline Streambed conductance... & \multicolumn{2}{|c|}{$\begin{array}{l}\text { Variable, from } 0.1 \text { to } 1.0 \mathrm{ft} / \mathrm{d} \\
\text { per } \mathrm{ft} \text { of streambed thickness. }\end{array}$} \\
\hline $\begin{array}{l}\text { Average total porosity }^{1} \\
\quad \text { (percent) } \ldots \ldots \ldots \ldots \ldots \ldots \ldots \ldots\end{array}$ & 20 & 20 \\
\hline $\begin{array}{l}\text { PDCN porosity }{ }^{1} \\
\quad \text { (percent)....... }\end{array}$ & 10 & 10 \\
\hline $\begin{array}{l}\text { STPR \& JRDN porosity }{ }^{1} \\
\quad \text { (percent) } \ldots \ldots \ldots \ldots\end{array}$ & 25 & 25 \\
\hline Saturated thickness (ft) $\ldots \ldots \ldots \ldots$ & 255 & 256 \\
\hline
\end{tabular}

${ }^{1}$ Hydrologic property value estimated based on published data (Norvitch and others, 1973). All other data in table 2 were obtained from (Delin, 1990)

\section{Zones of Contribution}

A zone of contribution is defined as all parts of a ground-water-flow system that could supply water to a well. Results of using the hydrogeologic and numerical-modeling methods are described below.

\section{Hydrogeologic Mapping}

Zones of contribution for Rochester wells 11 and 26 were delineated by use of the hydrogeologic-mapping method for a period of high and low potentiometric-surface gradients (August 1987 and January 1988, respectively). Reduced recharge and increased withdrawals from highcapacity wells (fig. 8) during the summer resulted in high potentiometric-surface gradients in August 1987 (fig. 6) compared to gradients in January 1988 (fig. 7). The 
downgradient and lateral positions of the dividing streamlines for Rochester wells 11 and 26 were estimated by use of the calculated zone-of-contribution method before the streamlines were extended upgradient to the ground-water divide.

The zones of contribution delineated by use of the hydrogeologic-mapping method appear as long strips or wedges (figs. 6 and 7). The boundaries of these zones are subjective and subject to seasonal influences. The zone of contribution for well 11 covered an area of about 13,440 acres during August 1987 (high-gradient conditions, fig. 6) compared to an area of about 4,100 acres during January 1988 (low-gradient conditions, fig. 7). Conversely, the zone of contribution changed very little for well 26, from 1,280 acres during August 1987 to 1,600 acres during January 1988 .

The Decorah-Platteville-Glenwood confining unit partially covers the zones of contribution for wells 11 and 26 (figs. 6 and 7); therefore, all parts of the overlying landscape contributing water to the edge (seepage area) of the confining unit overlying each contribution area should also be considered part of the zone of contribution for each well. This seepage area coincides with the zone of increased recharge described earlier. Nevertheless, because data are inadequate to determine which parts of the landscape above the confining unit actually deliver water to the zone of contribution, this area was not considered in delineation of the zones of contribution for wells 11 and 26 .

Well 11 is very close (about $700 \mathrm{ft}$ ) to the South Fork Zumbro River, and both field and numerical-model analyses indicate that the well induces infiltration of water from the river (Delin, 1990). Therefore, the watershed of the South Fork Zumbro River above well 11 (fig. 2), which extends westward into Dodge County and encompasses an area of about 160 square miles $\left(\mathrm{mi}^{2}\right)$, should be considered part of the zone of contribution for well 11. Based on numerical-model results (Delin, 1990), withdrawal of water from well 26 could induce infiltration of water from a small segment of Cascade Creek. If this induced infiltration actually occurred, the watershed above that stream segment (about $17 \mathrm{mi}^{2}$ ) should be considered part of the zone of contribution for well 26 .

\section{Numerical Model}

The model used in this study consists of a variably spaced grid of 64 rows and 52 columns (figs. 1 and 9). Grid spacings range from $1,000 \mathrm{ft}$ in Rochester to $11,100 \mathrm{ft}$ at the periphery of the model. Horizontal ground-water flow in the St. Peter-Prairie du Chien-Jordan aquifer was simulated with three model layers that represent, in descending order, the (1) St. Peter Sandstone, (2) Prairie du Chien Group of limestones and dolomites, and (3) Jordan Sandstone. Vertical flow in the ground-water system was simulated in the model by allowing leakage between model layers. Values of vertical and horizontal hydraulic conductivity, thickness, and initial hydraulic-head values for the aquifer were specified for each model node. Areal recharge was specified for the uppermost model layer. The values for the hydrogeologic properties relevant to this analysis are listed in table 1. The South Fork Zumbro River, Cascade Creek, and Bear Creek were simulated as head-dependent-flux cells in the model to allow ground-water discharge to and seepage from the streams. A detailed description of model construction, calibration, and limitations is provided by Delin (1990).

The model-computed zone of contribution for well 11 (fig. 10) covers about 2,180 acres and consists of several disconnected areas. The disconnected contribution areas south of the South Fork Zumbro River result primarily from the effects of pumping from other high-capacity wells in the area. Pumping from these high-capacity wells diverts ground water from south of the South Fork Zumbro River and captures water from within the zone of contribution for well 11; thus, gaps form in the zone (figs. 10 and 11). In addition, ground-water discharge to the South Fork Zumbro River (fig. 11) within the zone of contribution for well 11 further alters the area of the model-computed zone of contribution. Figure 11 is a conceptual illustration of ground-water flow from the top of the St. Peter-Prairie du Chien-Jordan aquifer to well 11 , other high-capacity wells, and the South Fork Zumbro River. As illustrated in this figure, the recharge areas delineated with the numerical model represent areas where water recharges the top of the aquifer. Flow of ground water through the upper carbonate aquifer and the Decorah-Platteville-Glenwood confining unit, where present, is not accounted for with the model.

It is important in the interpretation of the modelcomputed zones to remember that the numerical-model results represent steady-state conditions. That is, all stresses on the aquifer system, such as pumping, river leakage, and recharge, are simulated as constant in time. Pumping rates and aquifer recharge and discharge vary seasonally, however, thus altering the recharge areas of a well. Therefore, it may be prudent to consider the entire region encompassing the disconnected zone of contribution for well 11 and not just the disconnected zones themselves. The entire area encompassing the disconnected zones for well 11 covers about 19,200 acres (fig. 10).

The model-computed zone of contribution for well 26 covers about 320 acres (fig. 10). Based on the model results, pumping from other high-capacity wells has minimal effect on the zone of contribution for well 26, and the zone is not dissected, as is the case with well 11 . Based on the model results, however, pumping from well 26 could induce infiltration of water from Cascade Creek and could result in narrowing of the zone of contribution toward the creek upgradient from the well (fig. 10). Thus, the modelcomputed zone of contribution for well 26 does not extend to the ground-water divide (fig. 7). 


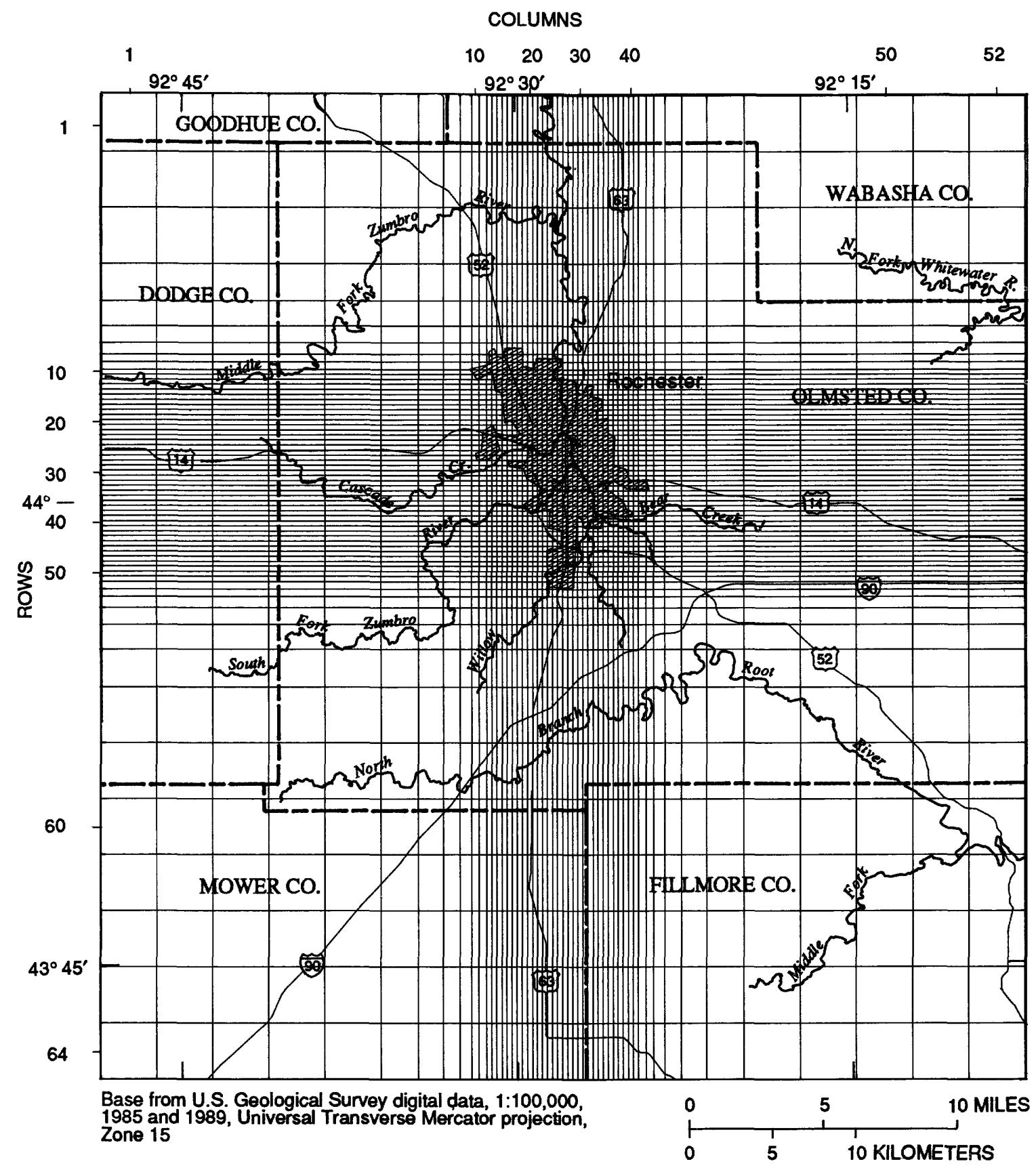

Figure 9. Finite-difference grid for the numerical model.

The effects of withdrawals from other high-capacity wells in the area on the size and shape of the modelcomputed zones of contribution was further evaluated by simulating withdrawals from wells 11 and 26 only. For these conditions, the zones of contribution for wells 11 and 26 cover about 2,620 and 640 acres, respectively. Comparison of figures 10 and 12 shows that a substantial part of the zone of contribution for well 11 south of the South Fork Zumbro River results from the influence of the other high-capacity wells in the area. Figure 12 shows that about
83 percent of the zone of contribution for well 11 is on the north side of the South Fork Zumbro River if only wells 11 and 26 are pumped, as compared to about 46 percent if all wells are pumped.

The disconnected parts of the zone of contribution for well 11 south of the South Fork Zumbro River (fig. 12) are likely inaccurate. These disconnected parts of the zone probably result from grid subdivisions that are too large to allow accurate tracking of water particles. As described earlier, this model was not specifically designed for 


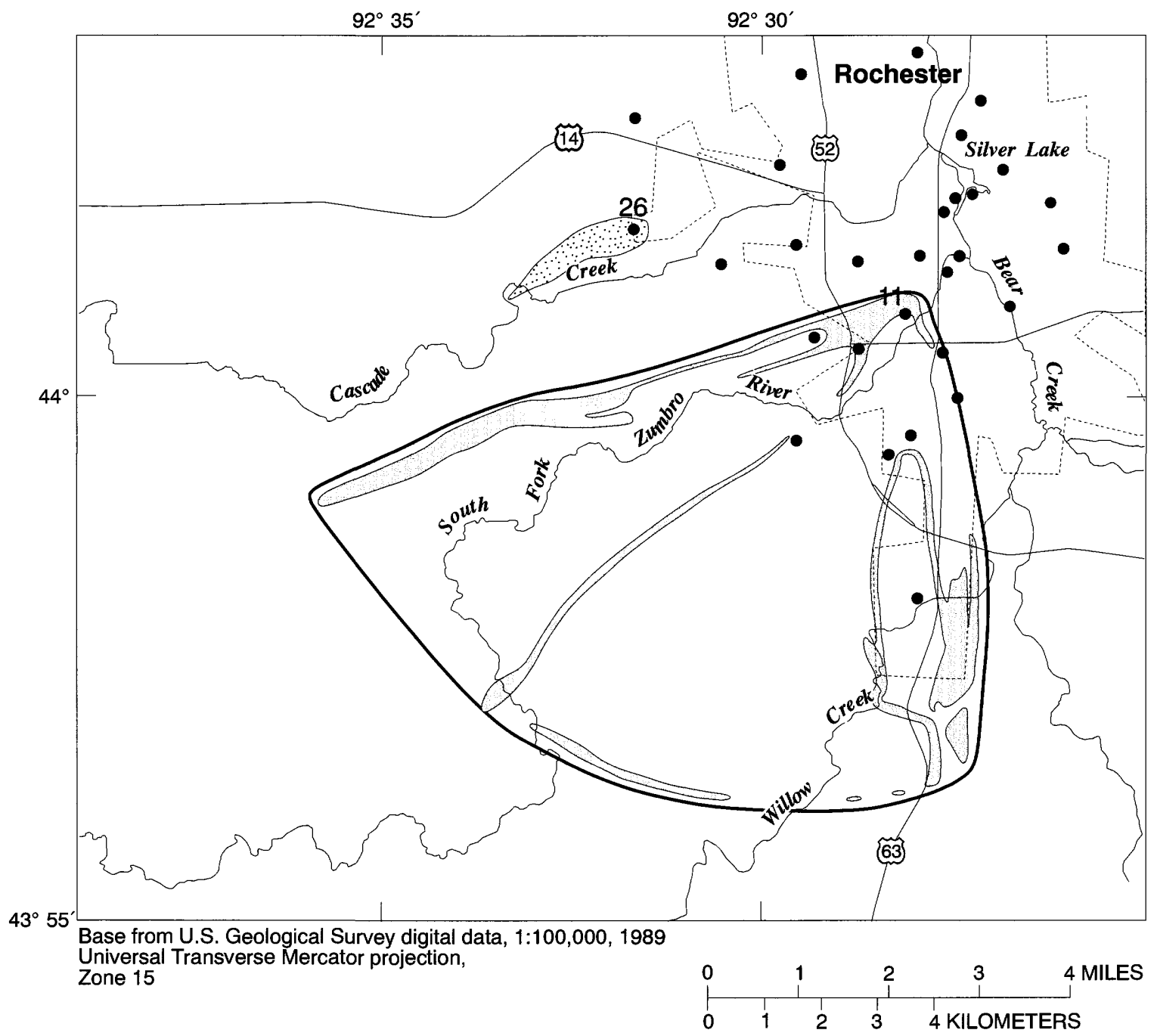

EXPLANATION

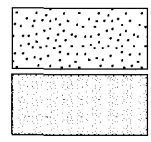

Zone of contribution for well 26

Disconnected zone of contribution for well 11

Boundary of region encompassing the disconnected zone of contribution for well 11

$.11 \quad$ Well location and number

- $\quad$ Other high-capacity well (discharge exceeds 200 gallons per minute)

Figure 10. Zones of contribution computed by use of the numerical model, all wells pumped.

delineating recharge areas for wells. Because of the large grid subdivisions, recharge to the aquifer is greater than ground-water discharge to the river, for some cells near well 11. When this condition happens, the particle-tracking program recognizes only a net inflow across the top of the cell and does not recognize a potential discharge point (well) in that cell. Thus, the effect of the river is eliminated locally and the resulting zone of contribution for well 11 is erroneously extended south of the river. Such an effect is simply a result of model grid subdivisions that are not fine 


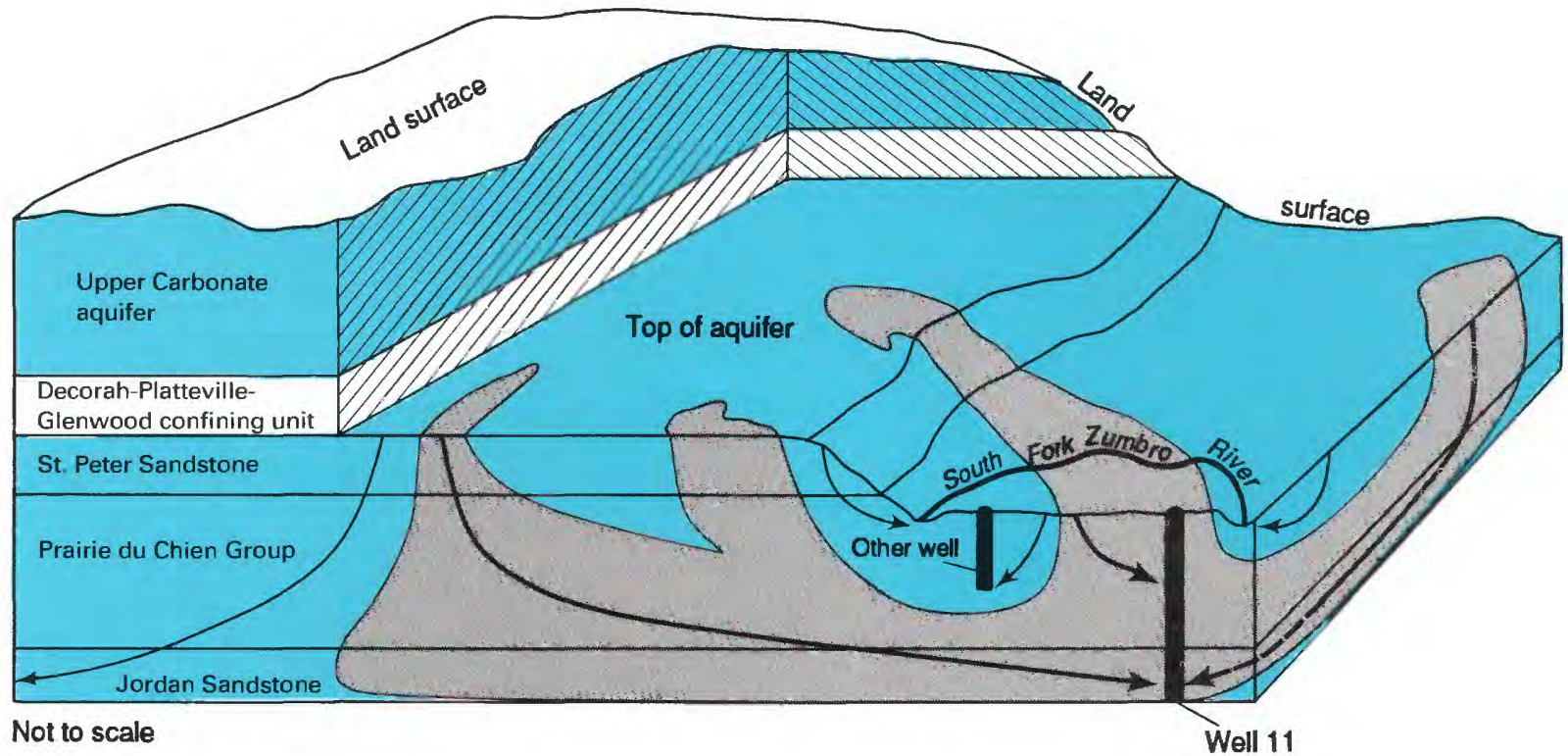

\section{EXPLANATION}

\section{Model-computed zone of contribution for well 11 \\ $\leftarrow-\quad$ Ground-water flow terminating at well 11, dashed where flow is not along face of block diagram}

\section{Other ground-water flow}

Figure 11. Conceptualized ground-water flow from the top of the St. Peter-Prairie du Chien-Jordan aquifer to well 11.

enough to differentiate between recharge to the aquifer and ground-water discharge to the South Fork Zumbro River.

\section{Zones of Transport}

A zone of transport is defined by the area around a pumped well bounded by lines of equal travel time. Results of using analytical and numerical-modeling methods are described below.

\section{Analytical Calculations}

Analytical calculations require simplification of the ground-water-flow system. Consequently, the relatively complex aquifer system in the Rochester area was treated as a uniform aquifer for the analytical calculations. Hydraulic properties used in calculations for each well (table 2) refer to average values for the entire thickness of the aquifer (the Prairie du Chien Group and the Jordan Sandstone). An average horizontal hydraulic conductivity, weighted by the relative thickness of each formation, was computed for the area around each well. Porosity is less well known and heterogeneous in the karstic Prairie du Chien Group. Because of this uncertainty, a porosity of 20 percent, rather than a strict weighted average, was used for the area around each well. This porosity was based on average values for the Prairie du Chien Group and the Jordan Sandstone in southeastern Minnesota (Norvitch and others, 1973). Likewise, an order-of-magnitude estimate for the storage coefficient, instead of a weighted average, was used for the area around well 26. For the area around well 11, however, sufficient hydraulic data were available to estimate a storage coefficient for the aquifer.

Fixed-radius methods

$$
\text { Theis drawdown }
$$

A limiting drawdown ( $D$, eq. 1$)$ of $0.05 \mathrm{ft}$ for wells 11 and 26 resulted in zones of influence on the order of miles for the Theis drawdown method. Because this recharge area is much larger than areas calculated by methods that consider time of transport, a drawdown limit of $5 \mathrm{ft}$ was selected for both wells to provide a better approximation of the zones of influence. For well 11, the 5-ft limitingdrawdown contour produced zones of influence with radii 


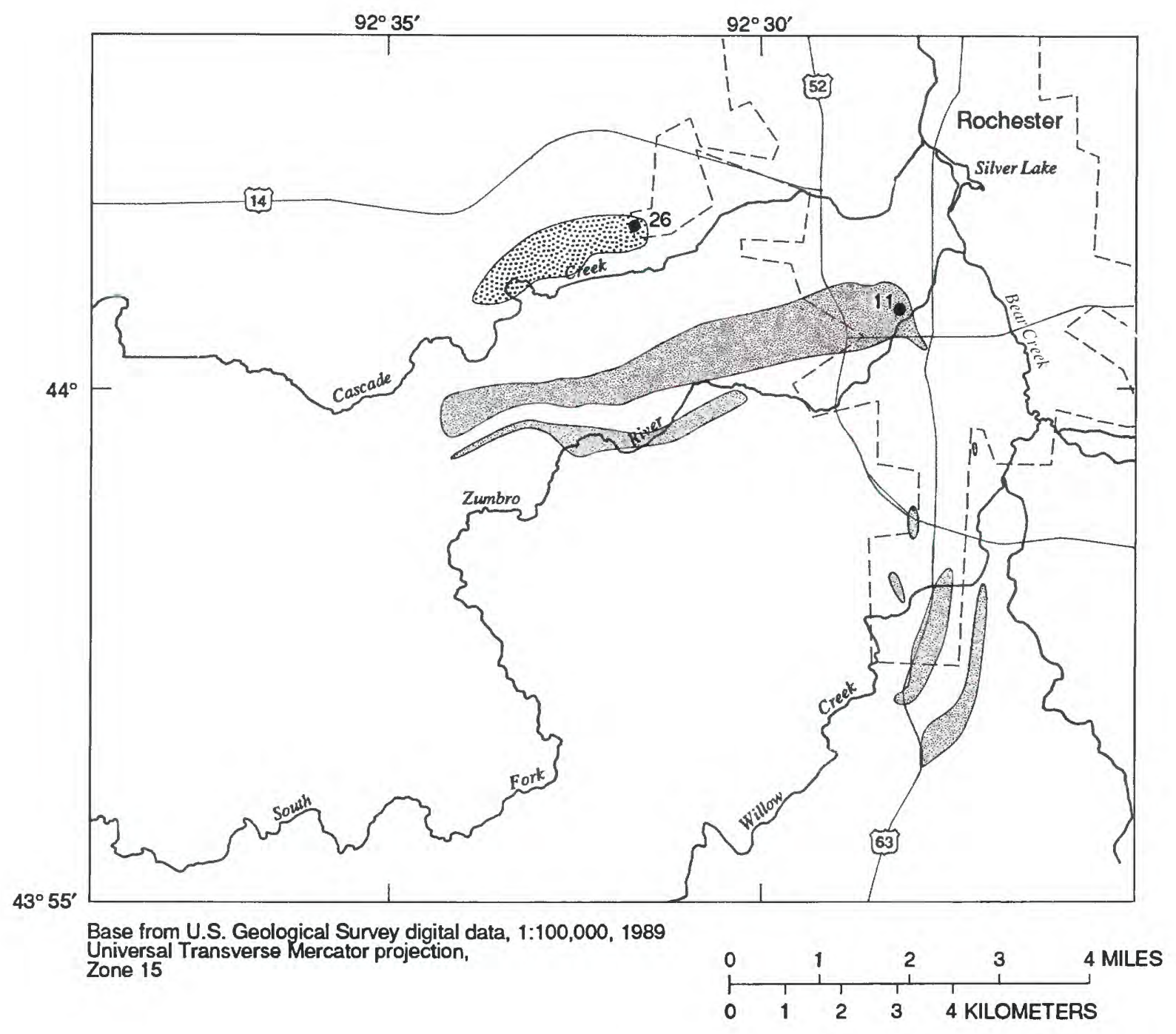

EXPLANATION

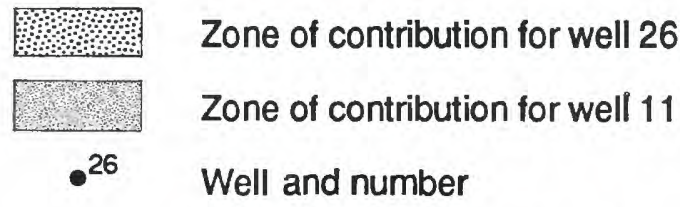

Figure 12. Zones of contribution computed by use of the numerical model, only wells 11 and 26 pumped.

of about $1,275,2,850$, and 4,025 $\mathrm{ft}$ for 1-, 5-, and 10-year pumping periods, respectively (fig. 13). For well 26, however, the 5 - $\mathrm{ft}$ drawdown contour produced zones of influence with radii of about 110,240 , and $340 \mathrm{ft}$ for 1-, 5-, and 10 -year pumping periods, respectively (fig. 13). The smaller radii for well 26 result from the lower discharge rate of this well and the higher horizontal hydraulic conductivity of the aquifer, as compared to well 11 (table 2).

It is important to keep in mind that most water-supply wells do not satisfy the assumptions of the Theis drawdown method. Even when the assumptions are met, correspon- dence is not good between the zone-of-influence size (1-, 5-, and 10-year drawdown contours) and the corresponding travel time of water in the aquifer. In addition, the zone size is entirely dependent on the arbitrary choice of a limiting drawdown, and the boundary effects of streams have not been accounted for by the image-well theory.

Theis time-of-travel

The Theis time-of-travel method produced zones of transport for well 11 with radii of roughly 425,950 , and 


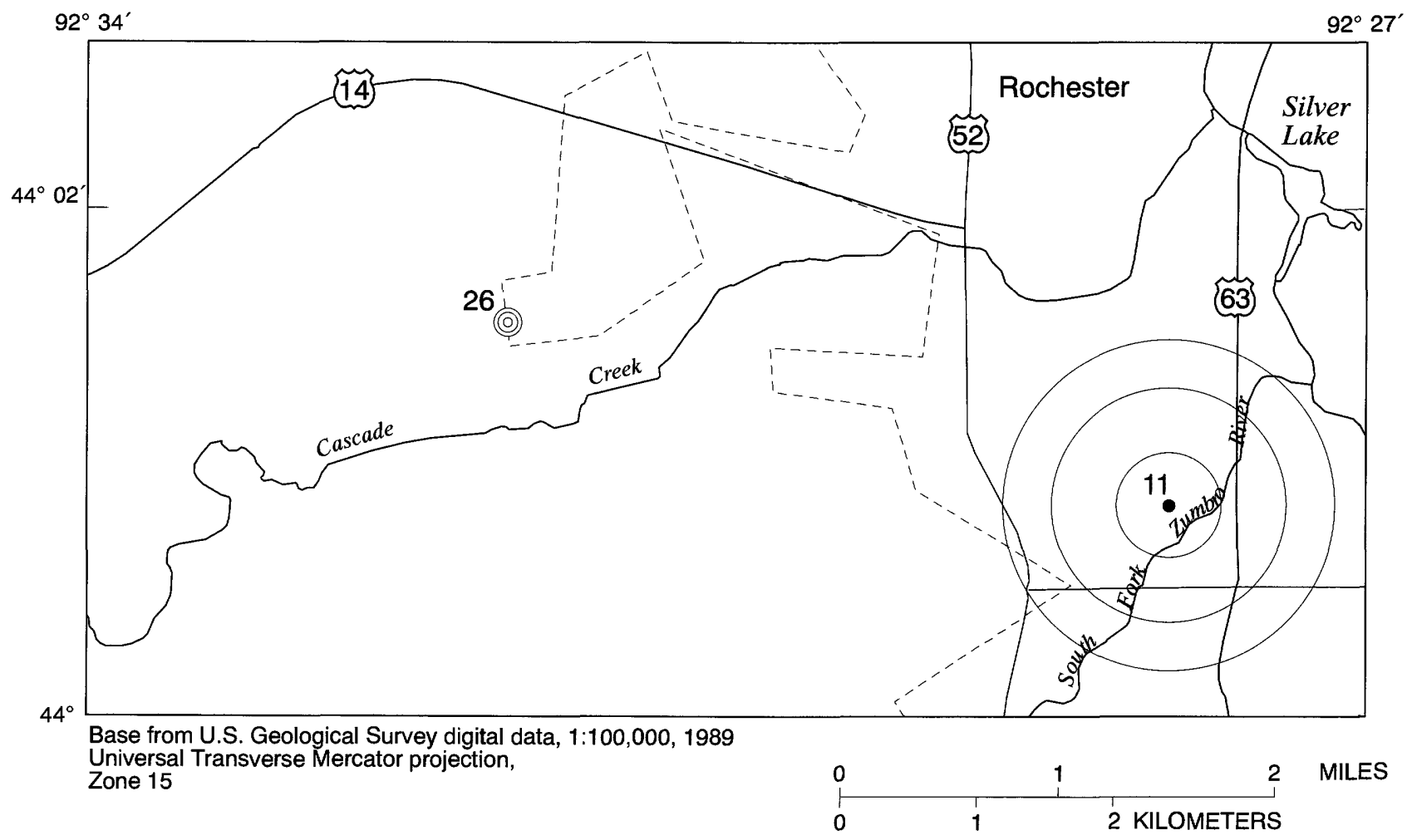

EXPLANATION

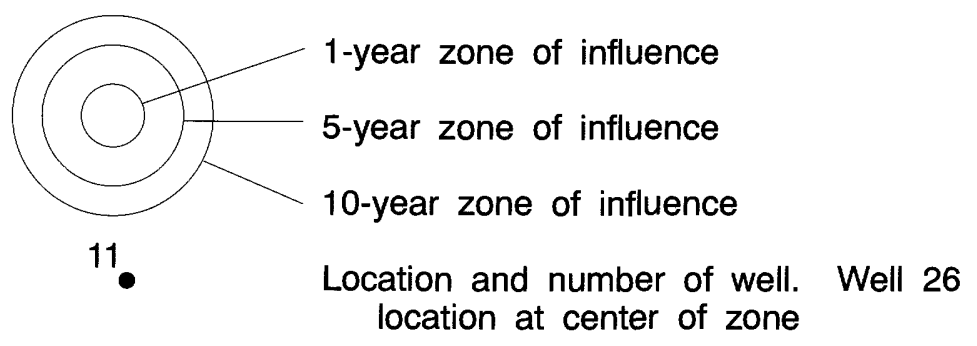

Figure 13. Zones of influence based on the Theis drawdown method, 5-foot drawdown limit.

$1,340 \mathrm{ft}$ for travel times of 1,5 , and 10 years, respectively. The corresponding zones of transport for well 26 have radii of about 200,450 , and $635 \mathrm{ft}$ (fig. 14). It is clear from figure 14 that the zones of transport for well 11 are substantially larger than those for well 26 , as would be expected from the fact that the pumping rate for well 11 is more than four times greater than the pumping rate for well 26 (table 2).

\section{Volumetric equation}

The 1-, 5-, and 10-year zones of transport produced by the volumetric-equation method have radii of about 425 , 955 , and $1,350 \mathrm{ft}$, respectively, for well 11 . The corresponding zones of transport for well 26 have radii of about
200, 450, and $635 \mathrm{ft}$ (fig. 15). The boundary effects of streams were not evaluated with use of image-well theory.

Variable-shape methods

$$
\text { Truncated parabola }
$$

The first step required for this method is to calculate a zone of contribution, or parabola. The locations of stagnation points $\left(X_{L}\right.$, eq 5) computed for the zone of contribution are about $1,070 \mathrm{ft}$ and $395 \mathrm{ft}$ downgradient from wells 11 and 26 , respectively. The corresponding limiting widths of the aquifer ( $w$, eqs 5 and 6) from which wells 11 and 26 capture flow are therefore about $6,750 \mathrm{ft}$ and 2,500 ft (figs. 16 and 17). A value for the uniform-flow 


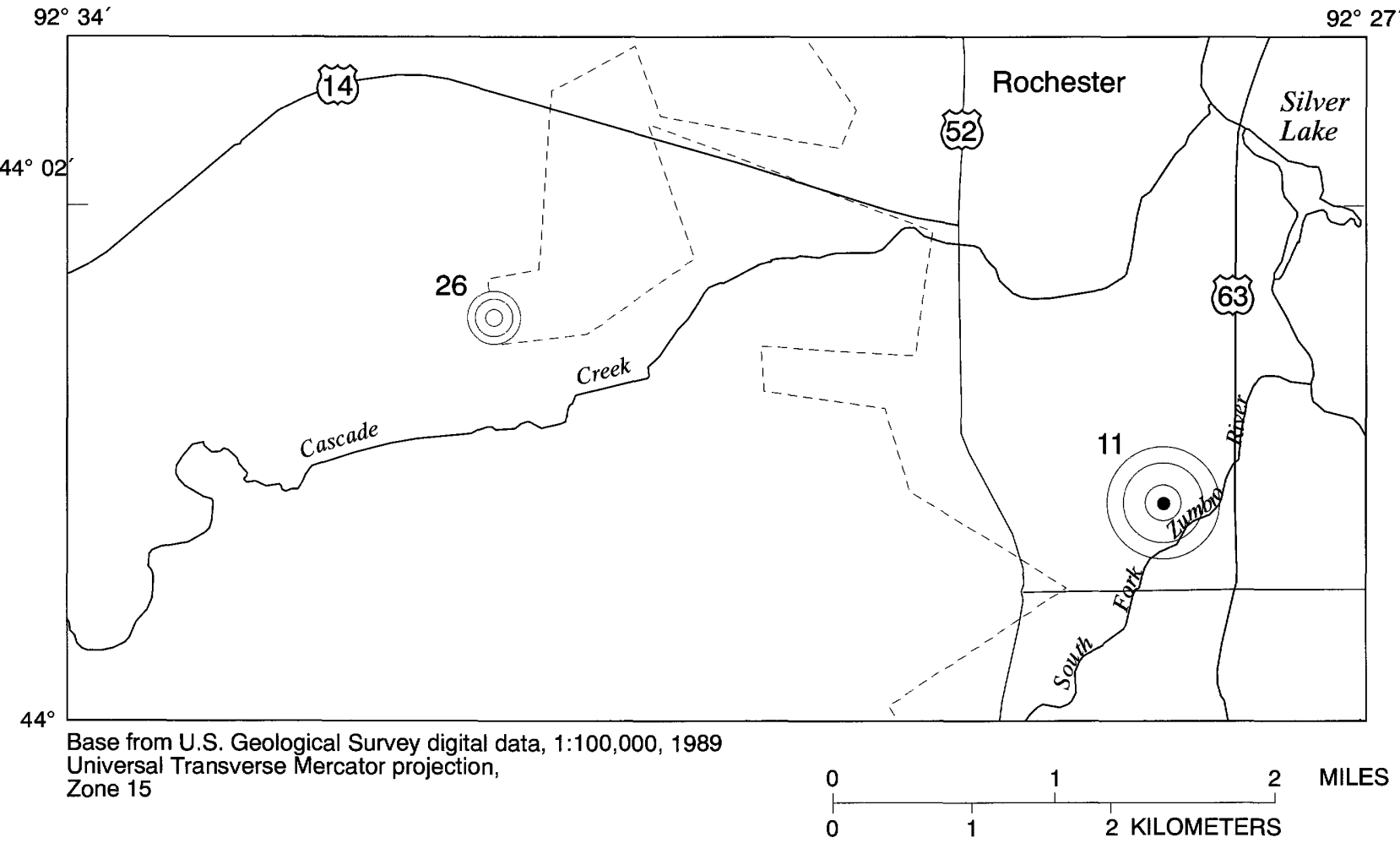

\section{EXPLANATION}

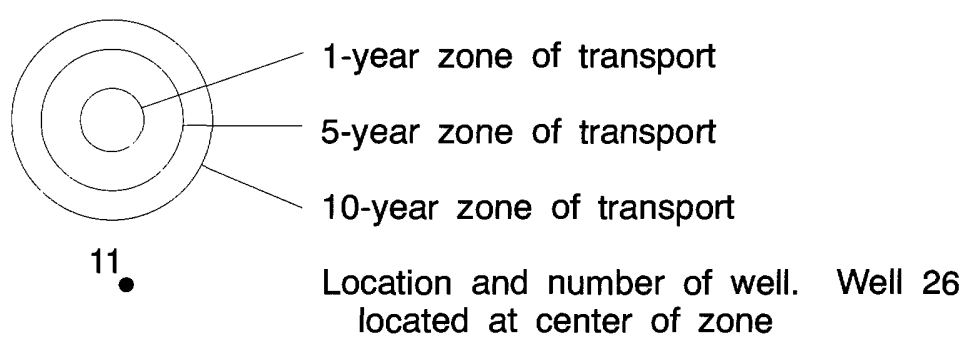

Figure 14. Zones of transport based on the Theis time-of-travel method.

gradient ( $i$, eqs 5 and 6) representing an average of the gradients for winter and summer conditions was used in calculating the zones of contribution for the wells. The boundary effects of streams were not evaluated with use of image-well theory.

The second step required for this method is to truncate the zone-of-contribution parabola by use of calculated water-particle travel times. The first procedure used was uniform flow. The uniform-flow procedure provided distances of travel for well 11 of about 85,425 , and $855 \mathrm{ft}$ for the 1-, 5-, and 10-year travel times, respectively. The corresponding distances for well 26 are about 50, 255, and $510 \mathrm{ft}$ (fig. 16). For both wells, therefore, the distances of travel are on the order of tens to hundreds of feet, whereas the limiting widths ( $w$, eqs 5 and 6 ) of the calculated zone of contribution are on the order of thousands of feet. Consequently, the resulting truncated-parabola zone of transport extends much farther in the downgradient and lateral directions from each well than it does in the upgradient direction.

The second procedure used to truncate the zone-ofcontribution parabola was Theis time-of-travel. As described earlier, the 10-year distances of travel computed with the Theis time-of-travel procedure are about 1,340 and $635 \mathrm{ft}$ for wells 11 and 26, respectively (fig. 17); however, these distances are still much smaller than the limiting widths ( $w$, eqs 5 and 6 ) of the calculated zones of contribution, about 6,750 and $2,500 \mathrm{ft}$ for wells 11 and 26 , respectively. Thus, as with the uniform-flow procedure, the resulting truncated-parabola zone of transport extends much 


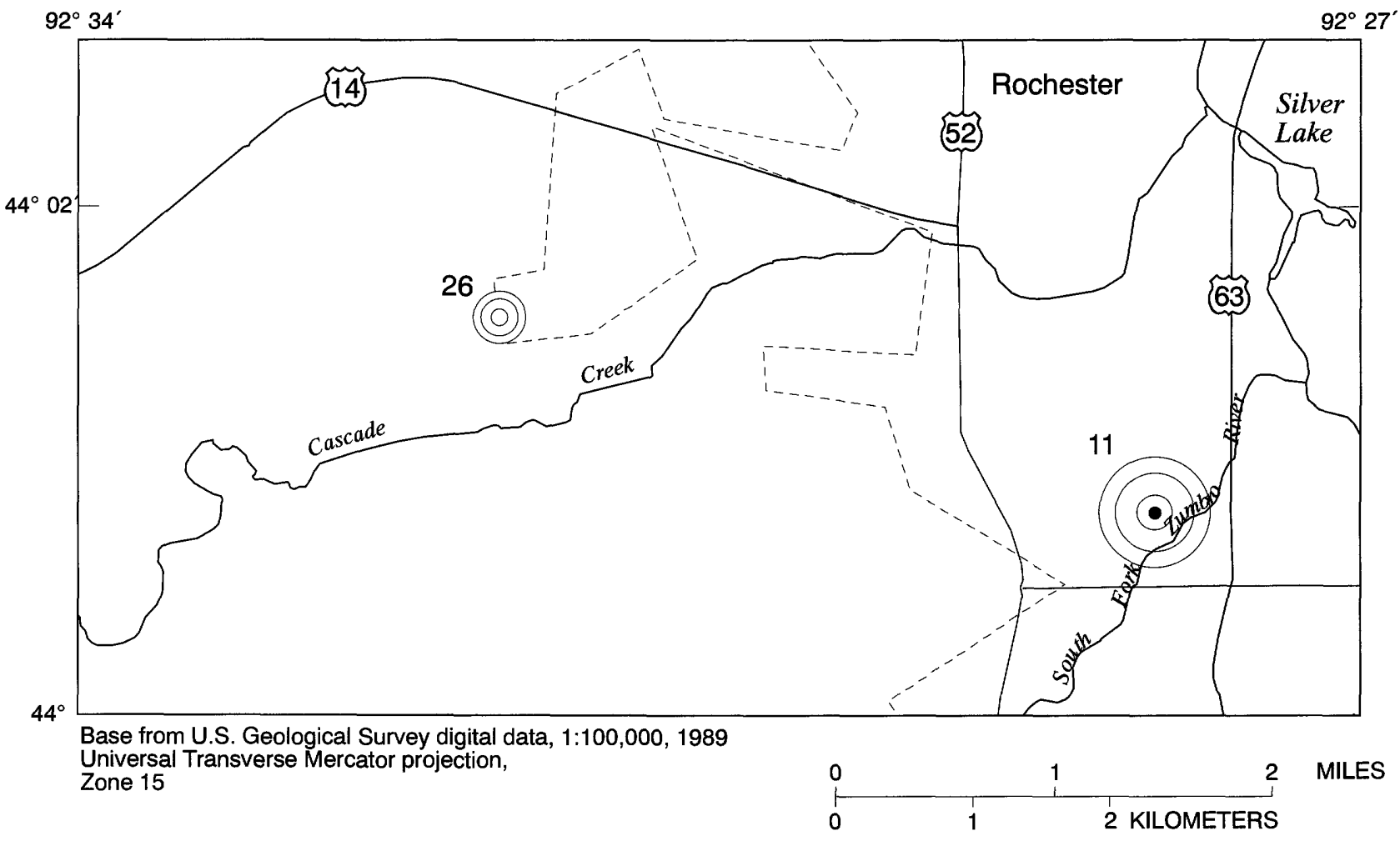

\section{EXPLANATION}

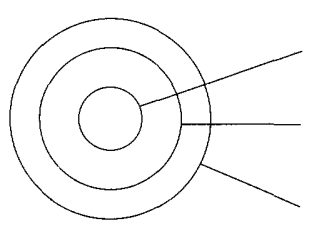

1-year zone of transport

5-year zone of transport

10-year zone of transport

11.

Location and number of well. Well 26 located at center of zone

Figure 15. Zones of transport based on the volumetric-equation method.

farther in the downgradient and lateral directions from the well than it does in the upgradient direction.

It is apparent from the results of the truncatedparabola method that the limiting widths of the calculated zone of contribution are greater than the distances of travel computed by use of the time-of-travel calculations. Consequently, the resulting zones of transport have impractical, and likely incorrect, shapes for wells 11 and 26 (figs. 16 and 17).

\section{Modified ellipse}

For well 11, the distances from the well to the upgradient boundary of the modified-ellipse zone of transport $(X+)$ are about $485,1,260$, and $1,970 \mathrm{ft}$ for $1-, 5-$, and 10-year travel times, respectively. The corresponding values for well 26 are about 235, 630, and 1,010 ft (fig. 18).

$$
\text { Simplified-variable-shape }
$$

Regional gradients are too strong in the Rochester area to allow use of a simple circular method for delineating simplified-variable-shape recharge areas. Similarly, regional gradients in the area are too low to form a well-defined zone of contribution that would allow use of the truncated-parabola method. The truncated-parabola method produces zones of transport that overestimate the recharge area downgradient from the well and underestimate the recharge area upgradient from the well. Consequently, the modified ellipse likely is the most appropriate 


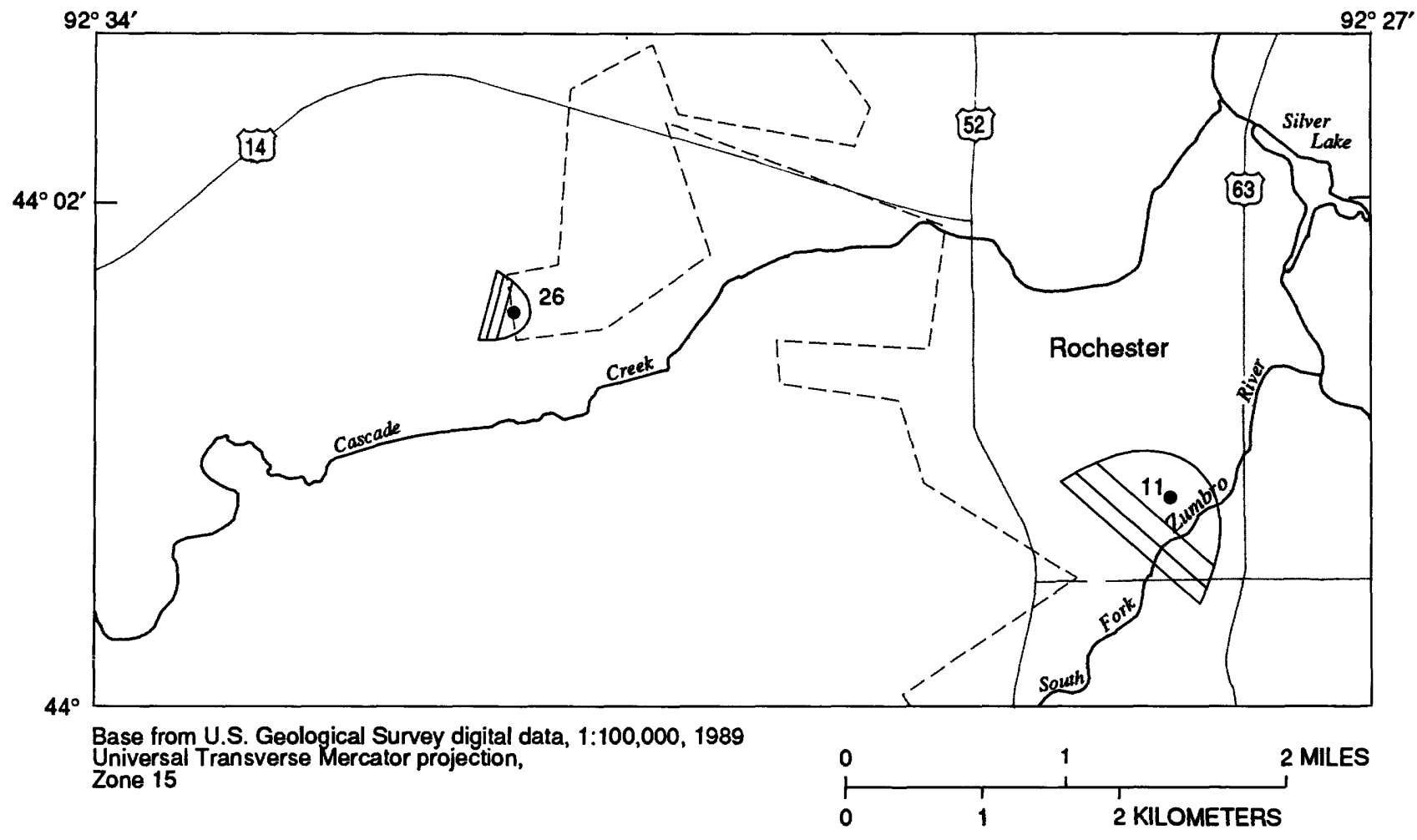

EXPLANATION

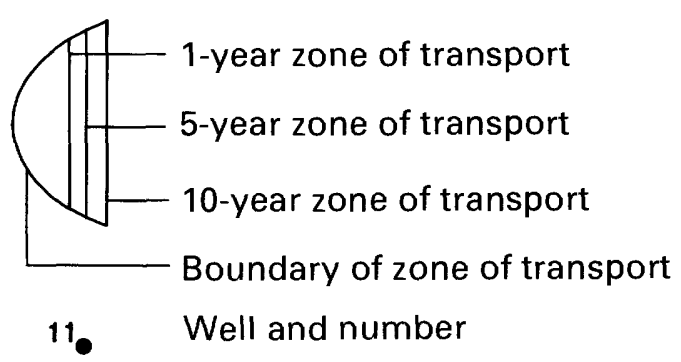

Figure 16. Zones of transport based on the truncated-parabola method, uniform-flow travel time.

analytical method to use in the Rochester area for constructing a set of simplified-variable shape recharge areas. Because this report is concerned only with two example wells for which the relevant hydrogeologic factors are known, construction of an entire set of modified ellipses covering the expected ranges of well discharge and hydraulic gradient for the region was beyond the scope of this study. Indeed, in the Rochester area it is possible that the karstic Prairie du Chien Group is too heterogeneous for meaningful application of a set of simplified variable shapes. Wells completed only in the Jordan Sandstone would perhaps be more suitable for this method.

\section{Numerical Model}

The 1-, 5-, and 10-year zone-of-transport areas computed by use of the numerical model for well 11 are about 40,100 , and 175 acres, respectively (fig. 19). Corresponding values for well 26 are about 30,65 , and 85 acres. The zones of transport computed by use of the numerical model generally have an angular outline, particularly for well 26 . This angularity is the result of the relative coarseness of model subdividing. The angularity of the zones of transport for well 26 is more noticeable because the well is in an area of larger cell size (fig. 9) as compared to well 11. Consequently, model-computed zones of transport for well 

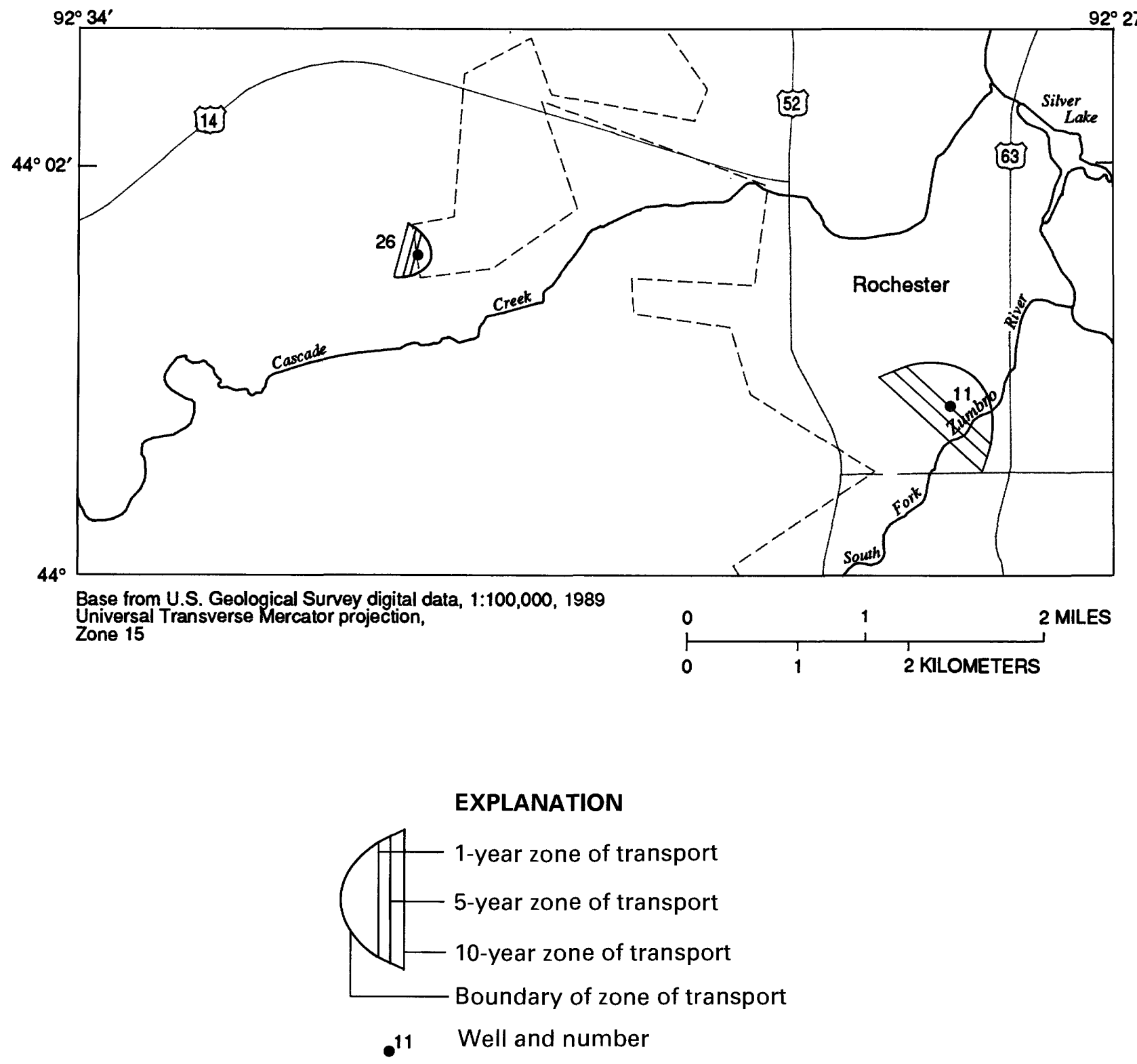

Figure 17. Zones of transport based on the truncated-parabola method, Theis travel time.

26 are expected to be less accurate than the zones computed for well 11 . The model-computed zones could be smoothed to obtain a more reasonable zone outline, but such smoothing was not done for this report. Smoother boundaries for the model-computed zones could be achieved if a more finely subdivided grid were used.

The 5- and 10-year zones of transport computed for well 11 by the model have a twin-lobed appearance (fig. 19). This feature results from the close proximity of the well to the river and from the effects of pumping at other high-capacity wells upgradient from well 11 . These other wells create a gap in the zone of transport by capturing ground water that would otherwise flow to well 11 . Note that the 1-year model-computed zone of transport for well
11 intersects the South Fork Zumbro River. This intersection, plus the fact that the South Fork Zumbro River is in direct communication with the aquifer (Delin, 1990), indicates that streamwater seeping into the aquifer could reach the well in less than 1 year.

\section{SENSITIVITY OF DELINEATED RECHARGE AREAS TO HYDROLOGIC FACTORS}

The sensitivity of the size and shape of the computed recharge areas relative to changes in the various hydrologic factors was examined for each method. Results of the sensitivity analyses can be used to determine where 


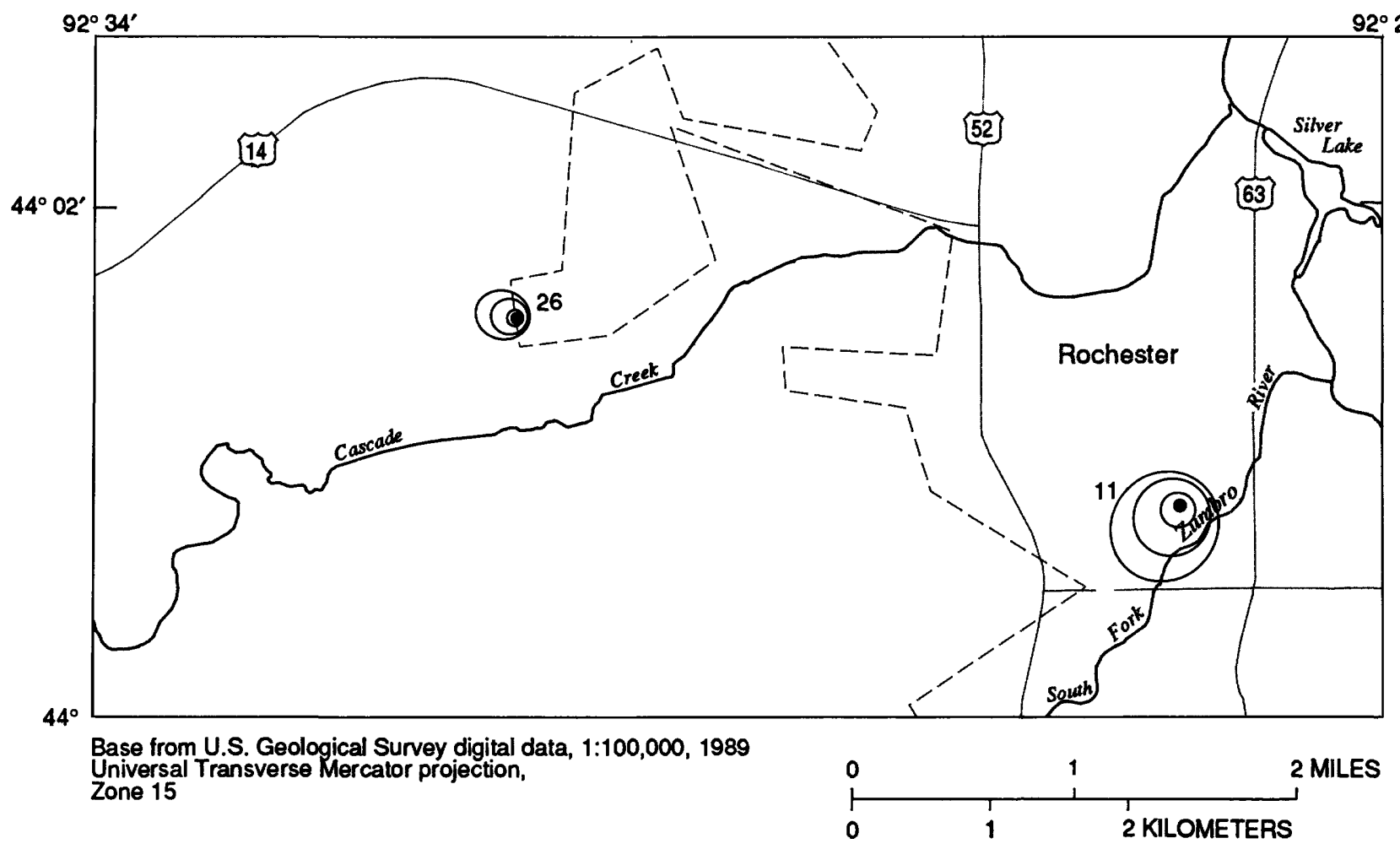

\section{EXPLANATION}

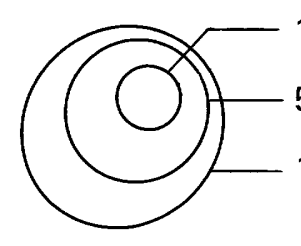

1-year zone of transport

5 -year zone of transport

10-year zone of transport

11. Well and number

Figure 18. Zones of transport based on the modified-ellipse method.

additional information about the hydrologic factors could improve knowledge of the ground-water-flow system and delineation of the recharge areas. Each hydrologic factor was varied over the probable range of values in the area. Each method requires a unique set of hydrologic factors, and the number of factors required depends on the complexity of the method. For example, the recharge areas delineated by use of the numerical-modeling method could be evaluated for sensitivity to changes in aquifer porosity, horizontal hydraulic conductivity, pumping rate, streambed vertical conductance, horizontal anisotropy, recharge, and influence from other wells. In contrast, recharge areas delineated by use of the hydrogeologic-mapping method could only be evaluated for sensitivity to the configuration of the potentiometric surface under a variety of pumping and climatic-stress conditions. The analytical methods were generally evaluated for their sensitivities, as applicable, to pumping rate, well construction, hydraulic gradient, horizontal hydraulic conductivity, and porosity. The sensitivity analysis for well construction consisted of calculating the recharge areas representative of the Prairie du Chien and Jordan parts of the aquifer at wells 11 and 26. Thus, the effects of changes in the hydrologic conditions for each individual formation was evaluated separately. 


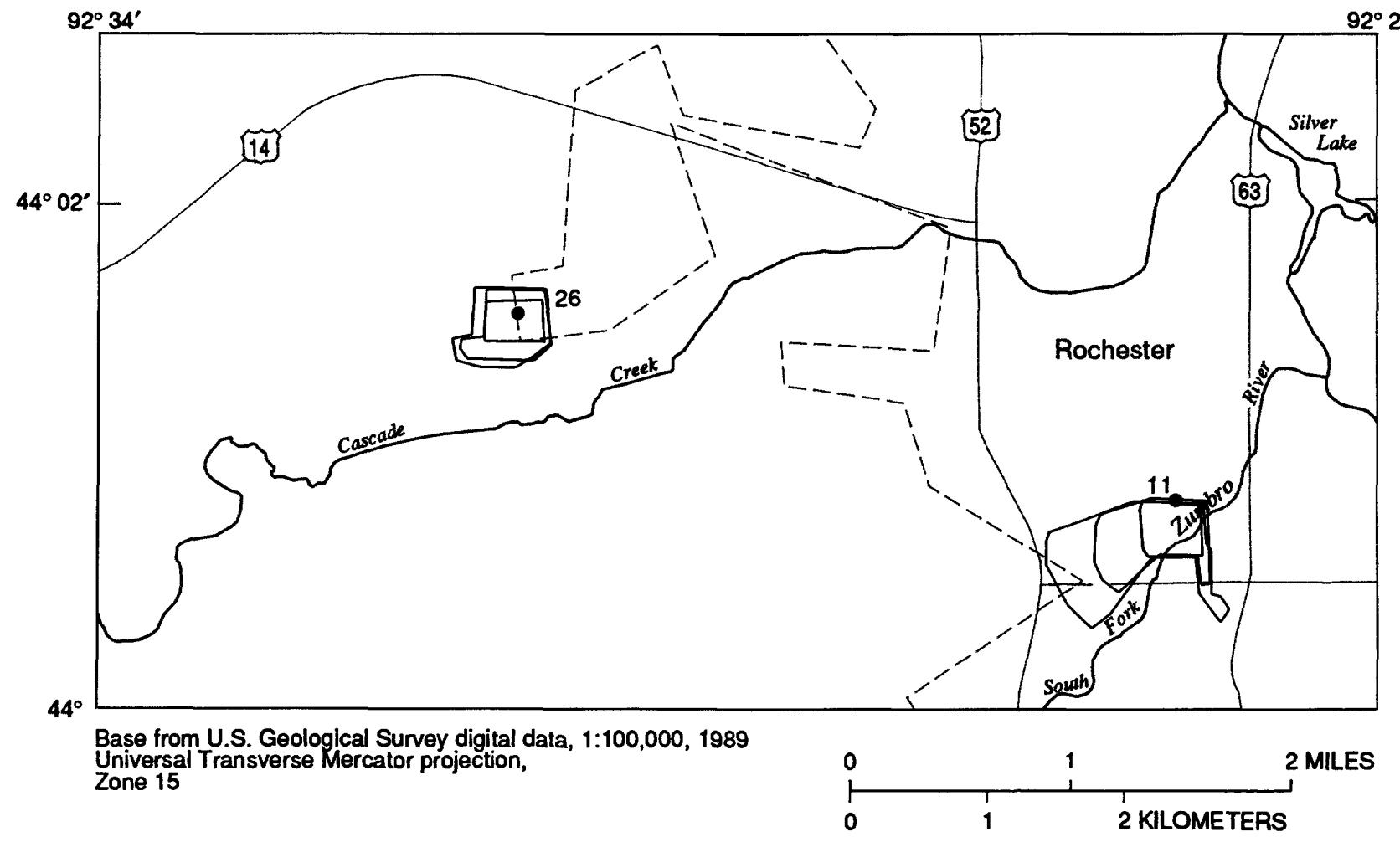

\section{EXPLANATION}

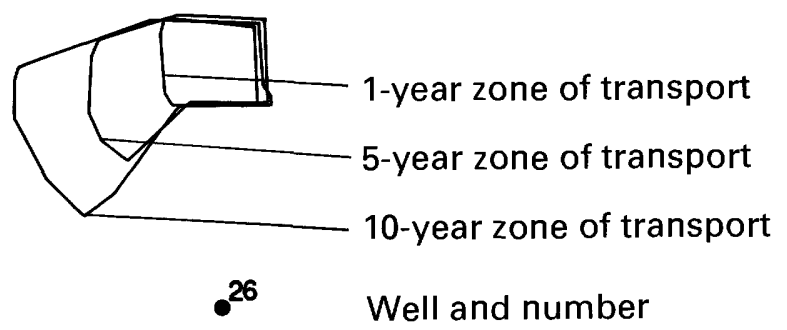

Figure 19. Zones of transport based on the numerical model.

\section{Zones of Contribution}

\section{Hydrogeologic-Mapping Method}

The zone-of-contribution areas delineated by use of the hydrogeologic-mapping method changed more for well 11 than for well 26 between August 1987 and January 1988 (figs. 6 and 7). This difference results largely from differences in the proximity of the wells to other high-capacity wells (fig. 8). Increased pumping during summer months causes a depression in the potentiometric surface of the aquifer in the Rochester area (fig. 6). Because well 11 is located relatively close to other high-capacity wells, this increased pumping resulted in a steepened potentiometricsurface gradient near well 11 during August 1987. Conse- quently, the steepened gradient exposed well 11 to a much wider angle of regional flow; the mapped zone of contribution was enlarged by a factor of about three. Because well 26 is located relatively distant from other high-capacity wells, increased pumping during summer months did not noticeably steepen the potentiometric-surface gradient near the well or significantly enlarge the zone of contribution.

The seasonal difference exhibited by the zones of contribution for wells 11 and 26 also exemplify a potential problem with the hydrogeologic-mapping method for determining a zone of contribution. The resolution of the boundary of the zone of contribution can be no better than the spacing of data used to construct the regional potentiometric-surface maps. In areas where the 
Table 3. Summary of recharge areas computed by use of each method

[Areas in acres, rounded to the nearest 5 acres]

Zones of Contribution

\begin{tabular}{|c|c|c|c|c|c|c|}
\hline \multicolumn{3}{|l|}{ Method } & \multicolumn{2}{|c|}{ Rochester Well 11} & \multicolumn{2}{|c|}{ Rochester Well 26} \\
\hline \multicolumn{7}{|l|}{ Hydrogeologic mapping: } \\
\hline \multicolumn{3}{|l|}{ High-gradient conditions... } & \multicolumn{2}{|c|}{13,440} & \multicolumn{2}{|c|}{1,280} \\
\hline Low-gradient conditions ...... & & \multicolumn{3}{|c|}{4,100} & \multicolumn{2}{|c|}{1,600} \\
\hline \multicolumn{7}{|l|}{ Numerical modeling: } \\
\hline Sum of disconnected areas (all wells pum & & \multicolumn{3}{|c|}{2,180} & \multicolumn{2}{|c|}{320} \\
\hline \multicolumn{7}{|l|}{ Entire region encompassing } \\
\hline disconnected areas (all wells pumping) & & & 19,2 & & \multicolumn{2}{|c|}{320} \\
\hline \multicolumn{7}{|l|}{ Sum of disconnected areas } \\
\hline (wells 11 and 26 pumping) & & & 2,6 & & \multicolumn{2}{|c|}{640} \\
\hline \multicolumn{7}{|c|}{ Zones of Transport } \\
\hline \multirow{2}{*}{ Method } & \multicolumn{3}{|c|}{ Rochester Well 11} & \multicolumn{3}{|c|}{ Rochester Well 26} \\
\hline & 1-year & 5-year & 10-year & 1-year & 5-year & 10-year \\
\hline Theis drawdown ${ }^{1}$. & 115 & 580 & 1,170 & 1 & 5 & 5 \\
\hline Theis time-of-travel. ................. & 15 & 65 & 130 & 5 & 15 & 30 \\
\hline Volumetric equation $\ldots \ldots \ldots \ldots \ldots \ldots$ & 15 & 65 & 135 & 5 & 15 & 30 \\
\hline \multicolumn{7}{|l|}{ Truncated parabola: } \\
\hline Uniform-flow equation $\ldots \ldots \ldots \ldots \ldots$ & 65 & 90 & 130 & 15 & 20 & 25 \\
\hline Theis time-of-travel ............... & 90 & 135 & 180 & 15 & 25 & 30 \\
\hline Modified ellipse ................. & 15 & 65 & 135 & 5 & 15 & 30 \\
\hline Numerical modeling . ............. & 40 & 100 & 175 & 30 & 65 & 85 \\
\hline
\end{tabular}

${ }^{1}$ Calculates zone of influence.

potentiometric-surface gradient is steep, such as near rivers, a zone of contribution can be delineated fairly accurately. For example, the mapped zone of contribution of well 26 changed very little from August 1987 to January 1988 partly because of the lack of local resolution of the potentiometric surface. Alternatively, the large change in the mapped zone of contribution of well 11 from August 1987 to January 1988 is, in part, a consequence of the steepness of potentiometric-surface gradient near well 11. Thus, the effects of increased pumping were more noticeable near well 11 than in areas distant from the South Fork Zumbro River. This problem could indicate that the hydrogeologicmapping method for delineating zones of contribution is more suited to simpler hydrogeologic settings, than complex hydrogeologic settings such as near Rochester.

\section{Numerical-Modeling Method}

Simulations of the effects of pumping from all wells in the area and from only wells 11 and 26 indicate that the zones of contribution are sensitive to changes in well location and pumping schemes. The size and shape of the model-computed zone of contribution for well 11 are sensitive to pumping from other high-capacity wells (figs. 10 and 12) because other wells are located nearby. In contrast, the zone of contribution for well 26 was not significantly altered by the effects of pumping from other high-capacity wells because other wells are not located nearby. The model-computed zones of contribution for wells 11 and 26 were also affected by their relative distance to nearby streams. The zone of contribution for well 11 was more noticeably affected, as evidenced by the disconnected contribution areas south of the South Fork Zumbro River, because the well is located relatively close to the river.

\section{Comparison of Methods}

The zones of contribution delineated by use of the hydrogeologic-mapping method differ greatly from the zones delineated by use of the numerical model (figs. 6, 7 , 10 , and 12). The zone of contribution delineated by use of hydrogeologic mapping for high-gradient conditions (fig. 6) is a relatively large wedge-shaped area covering about 13,440 acres that encompasses several wells and streams (table 3). In contrast, the zone delineated by use of the numerical model (fig. 10) produces a number of small, disconnected areas covering only about 2,180 acres. Although the area of the zone of contribution delineated by hydrogeologic mapping for low-gradient conditions (fig. 7) agrees more favorably with the area of the model-computed zone $(4,100$ acres $)$, the shape of the model-computed zone is quite different (fig. 10).

Further comparison of figures 6 and 10 illustrates that the area within an envelope encompassing all of the disconnected model-computed zone of contribution for well 11 does agree favorably in shape and area (19,200 acres) 
with the area delineated by use of the hydrogeologicmapping method for high-gradient conditions $(13,440$ acres). This comparison supports inclusion of the area encompassing the disconnected zone of contribution for well 11 as part of the zone of contribution for that well. In other words, it may make sense from a management perspective to include the area that encompasses the disconnected model-computed zone and to assume that any water within that envelope has a significant chance of discharging to the well. Of course, the entire area within the envelope cannot represent the zone of contribution for well 11 in the rigorous hydrologic sense. If this were the case, the annual recharge rate within the mapped zone of contribution would approximately equal the annual pumping rate for well 11 . However, the approximate annual pumping rate for well 11 ( $218 \mathrm{Mgal} / \mathrm{yr}$ ) is only about 15 percent of the approximate recharge to the aquifer system within the zone of contribution $(1,420 \mathrm{Mgal} / \mathrm{yr})$. Therefore, the remaining 85 percent of the water entering the aquifer within that area must discharge to the other high-capacity wells and to streams within the envelope. The detail in the water-level contours used in the hydrogeologic-mapping method, however, is not sufficient to resolve discharge to other wells or streams.

Because the numerical model can interpret groundwater discharge to other wells and to streams, smaller contribution areas are generated within the large zone of contribution produced by the hydrogeologic-mapping method. Therefore, the zone of contribution produced by the hydrogeologic-mapping method may be a more realistic representation of what is actually known about the source of water for well 11 than is the complex pattern that comes directly from the numerical-model analysis.

Regardless of the sophistication of numerical models, they should be used with caution when delineating extremely complex zones of contribution, particularly if the model-computed zones are intended for use in regulatory concerns. Initially, it may be tempting to conclude that the results of numerical modeling are better than the results of hydrogeologic mapping because model results appear to be more rigorous and accurate. That is not necessarily the case, however. When all of the assumptions, uncertainties, and limitations in a typical numerical model are considered, results of tracking water particles often turn out to be much less quantitative than might be expected. From a management perspective, numerical models ultimately are most valuable as educational tools to aid in the design of rational strategies and approaches to protecting ground-water quality. Numerical models can provide insight into the general characteristics of ground-water flow systems and provide an appreciation for their complexity.

The model-computed zone of contribution for well 26 (fig. 10), although not dissected, is also noticeably different than the zone delineated by use of the hydrogeologicmapping method (figs. 6 and 7). Based on the numericalmodel results, pumping from well 26 may induce infiltra- tion of water from nearby Cascade Creek. Consequently, the zone of contribution computed by use of the numerical model is smaller ( 320 acres) than the zone of contribution delineated by use of the hydrogeologic-mapping method $(1,280$ to 1,600 acres). In addition, the model-computed zone does not extend upgradient to the ground-water divide. The model results for wells 11 and 26 illustrate the versatility and advantages of the numerical-modeling method in simulating heterogeneities in the flow system that cannot be evaluated with the hydrogeologic-mapping method.

The zones of contribution delineated by use of the hydrogeologic-mapping method should have a similar orientation to those delineated by use of the numerical model, provided that the regional ground-water flow system is dominated by horizontal flow. This is generally true for the zones computed for both Rochester wells, although the model-computed zone of contribution for well 26 intersects Cascade Creek whereas the mapped zone of contribution does not.

\section{Zones of Transport}

\section{Theis Drawdown Method}

A sensitivity analysis indicated that the zones of influence computed by use of the Theis drawdown method are sensitive to changes in well discharge and horizontal hydraulic conductivity (table 4). The sensitivity is inversely proportional to well discharge. Because well 11 has the greater discharge rate, the zones of influence are less sensitive to changes in well discharge than are the zones of influence for well 26 . The zones of influence for well 26 are particularly sensitive to changes in horizontal hydraulic conductivity. At 0.3 times the horizontal hydraulic conductivity, the zone-of-influence radii increased by greater than 600 percent, whereas at 3 times the hydraulic conductivity the radii decreased by about 100 percent to unrealistically small values of less than $1 \mathrm{ft}$. The zones of influence computed by use of this method were not sensitive to well construction. In other words, the zones calculated for the Prairie du Chien and Jordan parts of wells 11 and 26 did not change significantly as compared to the changes calculated with averaged values for each well.

\section{Theis Time-of-Travel Method}

Based on results of the sensitivity analysis, the zones of transport computed by use of the Theis time-of-travel method are insensitive. A 25-percent change in pumping rate or porosity causes the zone-of-transport radii to change by only about 12 percent. Because the hydraulic gradient is independent of horizontal hydraulic conductivity with this method, it is also not sensitive to changes in the horizontal hydraulic conductivity when multiplied by factors of 3 and 
Table 4. Sensitivity of radii of zones of influence to changes in hydrologic factors, Theis drawdown method [Radii rounded to the nearest $5 \mathrm{ft}$ ]

\begin{tabular}{|c|c|c|c|c|c|c|}
\hline \multirow{3}{*}{ Hydrologic factor } & \multicolumn{6}{|c|}{ Radius of zone of influence, in $\mathrm{ft}$} \\
\hline & \multicolumn{3}{|c|}{ Well 11} & \multicolumn{3}{|c|}{ Well 26} \\
\hline & 1-year & 5-year & $\overline{10-y e a r}$ & 1-year & 5-year & $\overline{10-y e a r}$ \\
\hline $\begin{array}{l}\text { Horizontal hydraulic } \\
\text { conductivity } \times 0.3 \text {. }\end{array}$ & 1,240 & 2,775 & 3,925 & 780 & 1,745 & 2,465 \\
\hline Horizontal hydraulic & & & & & & \\
\hline conductivity $\times 3$. & 700 & 1,565 & 2,215 & .1 & .3 & .4 \\
\hline Average pumping rate $\times 0.75$. & 1,030 & 2,300 & 3,255 & 30 & 70 & 100 \\
\hline Average pumping rate $\times 1.25$. & 1,460 & 3,270 & 4,620 & 225 & 500 & 710 \\
\hline Best estimate (see table 2) .... & 1,275 & 2,850 & 4,025 & 110 & 240 & 340 \\
\hline
\end{tabular}

Table 5. Sensitivity of radii of zones of transport to changes in hydrologic factors, Theis time-of-travel method [Radii rounded to the nearest $5 \mathrm{ft}$ ]

\begin{tabular}{|c|c|c|c|c|c|c|}
\hline \multirow{3}{*}{ Hydrologic factor } & \multicolumn{6}{|c|}{ Radius of zone of transport, in $\mathrm{ft}$} \\
\hline & \multicolumn{3}{|c|}{ Well 11} & \multicolumn{3}{|c|}{ Well 26} \\
\hline & 1-year & 5-year & 10-year & 1-year & 5 -year & 10-year \\
\hline Porosity -5 percent & 495 & 1,100 & 1,545 & 230 & 520 & 730 \\
\hline Porosity +5 percent $\ldots$. & 380 & 850 & 1,200 & 180 & 400 & 570 \\
\hline \multicolumn{7}{|l|}{ Horizontal hydraulic } \\
\hline conductivity $\times 0.3 \ldots$ & 425 & 945 & 1,320 & 200 & 450 & 635 \\
\hline \multicolumn{7}{|l|}{ Horizontal hydraulic } \\
\hline conductivity $\times 3$.. & 430 & 955 & 1,345 & 200 & 450 & 635 \\
\hline Average pumping rate $\times 0.75$. & 370 & 825 & 1,165 & 175 & 390 & 550 \\
\hline Average pumping rate $\times 1.25 \ldots$ & 480 & 1,065 & 1,500 & 225 & 500 & 710 \\
\hline Best estimate (see table 2$) \ldots \ldots \ldots \ldots \ldots$ & 425 & 950 & 1,340 & 200 & 450 & 635 \\
\hline
\end{tabular}

Table 6. Sensitivity of radii of zones of transport to changes in hydrologic factors, volumetric-equation method [Radii rounded to the nearest $5 \mathrm{ft}$ ]

\begin{tabular}{|c|c|c|c|c|c|c|}
\hline \multirow{3}{*}{ Hydrologic factor } & \multicolumn{6}{|c|}{ Radius of zone of transport, in $\mathrm{ft}$} \\
\hline & \multicolumn{3}{|c|}{ Well 11} & \multicolumn{3}{|c|}{ Well 26} \\
\hline & 1-year & 5-year & 10-year & 1-year & 5-year & 10-year \\
\hline Porosity +5 percent & 495 & 1,100 & 1,560 & 230 & 515 & 730 \\
\hline Porosity -5 percent & 380 & 855 & 1,205 & 180 & 400 & 565 \\
\hline Average pumping rate $\times 0.75$. & 370 & 825 & 1,170 & 175 & 390 & 550 \\
\hline Average pumping rate $\times 1.25$. & 475 & 1,065 & 1,510 & 225 & 500 & 710 \\
\hline Best estimate (see table 2 ). & 425 & 955 & 1,350 & 200 & 450 & 635 \\
\hline
\end{tabular}

0.3 (table 5). The zones of transport computed by use of this method were sensitive to well construction relative to changes in the porosity of the Prairie du Chien Group. In other words, the zones calculated for the Prairie du Chien part of wells 11 and 26 changed substantially as compared to the changes calculated with averaged values for each well. A 25-percent change in the porosity of the Prairie du Chien Group caused the zone-of-transport radii to change by about 40 percent.

\section{Volumetric-Equation Method}

A sensitivity analysis indicated that the zones of transport generated by the volumetric-equation method are not sensitive to changes in values of well discharge and porosity. Changing the well discharge and porosity by 25 percent caused the zone-of-transport radius to change by about 12 percent (table 6 ). The zones of transport computed by use of this method were sensitive to well construction relative to changes in the porosity of the Prairie du Chien Group. A 25-percent change in porosity of the Prairie du Chien changed the radii of the zones by about 40 percent.

\section{Truncated-Parabola Method}

As discussed previously, the location of the stagnation point for the truncated-parabola method is directly proportional to well discharge and inversely proportional to 
horizontal hydraulic conductivity or hydraulic gradient. Results of the sensitivity analysis (table 7) support these conclusions. The sensitivity of the uniform-flow procedure for truncating the parabola to changes in hydraulic conductivity and hydraulic gradient, as described earlier, may be computed directly from equation 8 (table 8 ). The sensitivity of the Theis time-of-travel procedure for truncating the parabola was described earlier and is summarized in table 5. The zones computed by use of the uniform-flow procedure were sensitive to well construction relative to changes in the porosity of the Prairie du Chien Group. A 25-percent change in the porosity of the Prairie du Chien Group caused the distance of travel to change by about 100 percent.

\section{Modified-Ellipse Method}

Sensitivity of the distance between the well and the upgradient boundary of the modified ellipse zone of transport was examined relative to changes in well discharge, hydraulic gradient, horizontal hydraulic conductivity, and porosity (table 9). Overall, the modified-ellipse method was
Table 7. Sensitivity of distance to the stagnation point downgradient from a well computed for the calculated zones of contribution to changes in hydrologic factors, truncated-parabola method

$\left[X_{L}\right.$, distance to stagnation point downgradient from well, rounded to the nearest $5 \mathrm{ft}$. Regional hydraulic gradients: for well 11 , high $=0.14$ and low $=0.004$; for well 26 , high $=0.004$ and low $=0.003$ ]

\begin{tabular}{|c|c|c|}
\hline \multirow[b]{2}{*}{ Hydrologic factor } & \multicolumn{2}{|c|}{$X_{L}$ distance, in $\mathrm{ft}$} \\
\hline & Well 11 & Well 26 \\
\hline \multicolumn{3}{|l|}{ Horizontal hydraulic } \\
\hline conductivity $\times 0.3$. & 3,555 & 1,310 \\
\hline \multicolumn{3}{|l|}{ Horizontal hydraulic } \\
\hline conductivity $\times 3$.. & 355 & 130 \\
\hline Average pumping rate $\times 0.75 \ldots \ldots \ldots$ & 800 & 295 \\
\hline Average pumping rate $\times 1.25 \ldots \ldots \ldots$ & 1,335 & 490 \\
\hline \multicolumn{3}{|l|}{ High regional } \\
\hline hydraulic gradient... & 685 & 345 \\
\hline \multicolumn{3}{|l|}{ Low regional } \\
\hline hydraulic gradient ..... & 2,400 & 460 \\
\hline Best estimate (see table 2 ). & 1,070 & 395 \\
\hline
\end{tabular}

Table 8. Sensitivity of distance of travel to changes in hydrologic factors, uniform-flow procedure for truncated-parabola method

[Regional hydraulic gradients: for well 11 , high $=0.14$ and low $=0.004$; for well 26 , high $=0.004$ and low $=0.003$. Distance of travel rounded to the nearest $5 \mathrm{ft}]$

\begin{tabular}{|c|c|c|c|c|c|c|}
\hline \multirow{3}{*}{ Hydrologic Factor } & \multicolumn{6}{|c|}{ Distance of travel, in $\mathrm{ft}$} \\
\hline & \multicolumn{3}{|c|}{ Well 11} & \multicolumn{3}{|c|}{ Well 26} \\
\hline & 1-year & 5-year & 10-year & 1-year & 5-year & 10-year \\
\hline Porosity -5 percent $\ldots \ldots \ldots \ldots \ldots \ldots$ & 115 & 570 & 1,140 & 70 & 340 & 680 \\
\hline Porosity +5 percent $\ldots \ldots \ldots \ldots \ldots \ldots$ & 70 & 340 & 685 & 40 & 205 & 410 \\
\hline Horizontal hydraulic conductivity $\times 0.3$. . & 25 & 130 & 255 & 15 & 75 & 155 \\
\hline Horizontal hydraulic conductivity $\times 3 \ldots$ & 255 & 1,280 & 2,560 & 155 & 765 & 1,535 \\
\hline High regional hydraulic gradient........ & 135 & 665 & 1,330 & 60 & 290 & 585 \\
\hline Low regional hydraulic gradient $\ldots \ldots \ldots$ & 40 & 190 & 380 & 45 & 220 & 440 \\
\hline Best estimate (see table 2 ) ........... & 85 & 425 & 855 & 50 & 255 & 510 \\
\hline
\end{tabular}

Table 9. Sensitivity of distance between well and upgradient boundary of zone of transport to changes in hydrologic factors, modified-ellipse method

$[X+$, distance between well and upgradient boundary of modified ellipse zone of transport, rounded to the nearest $5 \mathrm{ft}$. Regional hydraulic gradients: for well 11 , high $=0.14$ and low $=0.004$; for well 26 , high $=0.004$ and low $=0.003$ ]

\begin{tabular}{|c|c|c|c|c|c|c|}
\hline \multirow{3}{*}{ Hydrologic factor } & \multicolumn{6}{|c|}{$X+$ distance, in $\mathrm{ft}$} \\
\hline & \multicolumn{3}{|c|}{ Well 11} & \multicolumn{3}{|c|}{ Well 26} \\
\hline & 1-year & 5-year & 10-year & 1-year & 5-year & 10-year \\
\hline Porosity -5 percent . & 570 & 1,510 & 2,395 & 280 & 765 & 1,240 \\
\hline Porosity +5 percent & 430 & 1,095 & 1,700 & 205 & 545 & 870 \\
\hline Horizontal hydraulic conductivity $\times 0.3$. & 445 & 1,040 & 1,525 & 210 & 500 & 740 \\
\hline Horizontal hydraulic conductivity $\times 3 \ldots$ & 610 & 1,945 & 3,400 & 315 & 1,055 & 1,890 \\
\hline Average pumping rate $\times 0.75 \ldots \ldots \ldots$ & 430 & 1,135 & 1,795 & 210 & 575 & 930 \\
\hline Average pumping rate $\times 1.25 \ldots \ldots \ldots \ldots$ & 535 & 1,370 & 2,125 & 260 & 685 & 1,085 \\
\hline High regional hydraulic gradient........ & 520 & 1,440 & 2,350 & 240 & 660 & 1,070 \\
\hline Low regional hydraulic gradient ........ & 455 & 1,085 & 1,615 & 230 & 605 & 955 \\
\hline Best estimate (see table 2 ) ........... & 485 & 1,260 & 1,970 & 235 & 630 & 1,010 \\
\hline
\end{tabular}


Table 10. Sensitivity of zone-of-transport areas to changes in hydrologic factors, numerical-modeling method

[STPR, St. Peter Sandstone; PDCN, Prairie du Chien Group; JRDN, Jordan Sandstone; 1:3, East-West horizontal hydraulic conductivity is three times the North-South hydraulic conductivity. (The steady-state average was assumed to be isotropic ${ }^{1}$.) Steady-state average porosity values, in percent: STPR, 25 ; PDCN, 10; JRDN, 25. See table 2 for the average values of the other variables. Areas rounded to the nearest 5 acres]

\begin{tabular}{|c|c|c|c|c|c|c|}
\hline \multirow{3}{*}{ Hydrologic factor } & \multicolumn{6}{|c|}{ Zone-of-transport area, in acres } \\
\hline & \multicolumn{3}{|c|}{ Well 11} & \multicolumn{3}{|c|}{ Well 26} \\
\hline & 1-year & 5-year & 10-year & 1-year & 5 -year & 10-year \\
\hline PDCN porosity $\times 0.25$ & 90 & 245 & 340 & 45 & 130 & 175 \\
\hline PDCN porosity $\times 1.5$. & 30 & 65 & 115 & 30 & 50 & 70 \\
\hline STPR \& JRDN porosity $\times 0.8$. & 40 & 95 & 175 & 30 & 65 & 90 \\
\hline STPR \& JRDN porosity $\times 1.2$. & 40 & 95 & 160 & 30 & 65 & 85 \\
\hline Anisotropy $^{2}: 3: 1$ for STPR, PDCN, \& JRDN. & 40 & 110 & 175 & 45 & 70 & 90 \\
\hline Anisotropy $^{2}: 1: 3$ for STPR, PDCN, \& JRDN. & 40 & 85 & 135 & 30 & 60 & 85 \\
\hline Anisotropy $^{2}: 3: 1$ for PDCN only $\ldots \ldots \ldots \ldots \ldots$ & 45 & 130 & 205 & 45 & 65 & 85 \\
\hline Anisotropy $^{2}: 1: 3$ for PDCN only.... & 30 & 75 & 135 & 30 & 60 & 75 \\
\hline \multicolumn{7}{|l|}{ Horizontal hydraulic conductivity of STPR, PDCN, \& } \\
\hline JRDN $\times 3 \ldots \ldots \ldots \ldots \ldots \ldots$ & 50 & 130 & 200 & 45 & 95 & 130 \\
\hline \multicolumn{7}{|l|}{ Horizontal hydraulic conductivity of STPR, PDCN, \& } \\
\hline $\mathrm{JRDN} \times 0.3 \ldots \ldots$ & 40 & 75 & 120 & 30 & 45 & 70 \\
\hline Vertical hydraulic conductivity $\times 0.1$ & 70 & 95 & 180 & 30 & 50 & 75 \\
\hline Vertical hydraulic conductivity $\times 10 \ldots \ldots \ldots \ldots \ldots$ & 30 & 90 & 140 & 30 & 60 & 75 \\
\hline Average pumping rate $\times 0.75 \ldots \ldots \ldots \ldots$ & 40 & 115 & 120 & 30 & 60 & 65 \\
\hline Average pumping rate $\times 1.25 \ldots \ldots \ldots \ldots \ldots \ldots \ldots$ & 40 & 95 & 165 & 30 & 65 & 90 \\
\hline Pumping simulated only for Rochester wells 11 and 26 . & 40 & 90 & 145 & 30 & 65 & 85 \\
\hline Streambed conductance $\times 0.1 \ldots$ & 40 & 90 & 145 & 30 & 60 & 65 \\
\hline Streambed conductance $\times 10$. . & 50 & 90 & 155 & 30 & 60 & 85 \\
\hline Recharge rate $\times 0.75 \ldots \ldots$. & 45 & 100 & 175 & 30 & 60 & 90 \\
\hline Recharge rate $\times 1.25 \ldots \ldots \ldots$ & 40 & 95 & 180 & 30 & 65 & 75 \\
\hline Steady-state average .......... & 40 & 100 & 175 & 30 & 65 & 85 \\
\hline
\end{tabular}

${ }^{1}$ Isotropy is that condition in which all hydraulic properties of an aquifer are independent of direction.

${ }^{2}$ Anisotropy is that condition in which the value of the hydraulic properties of an aquifer depend upon the direction in which they are measured.

not sensitive. A change in any of these factors generally produced a smaller percentage change in the distance from the well to the upgradient boundary of the zone. For example, a 25-percent change in either well discharge or horizontal hydraulic conductivity caused the distance to the upgradient boundary to change by only about 12 percent. Zones of transport computed by use of this method, however, were sensitive to well construction relative to changes in the porosity of the Prairie du Chien Group. A 25-percent change in the porosity of the Prairie du Chien Group caused the distance of travel to change by about 50 to 70 percent.

\section{Numerical-Modeling Method}

Values of the hydrologic factors used in the numerical model were varied within their expected range to evaluate their effects on the size and shape of the computed zones of transport. The hydrologic factors evaluated in this sensitivity analysis include vertical and horizontal hydraulic conductivity, porosity, conductance of the streambed material, horizontal anisotropy, ground-water pumpage rates, and average annual recharge rates (table 10). The modelcomputed zone-of-transport areas listed in table 10 were estimated to within about 5 acres.
Effects of changes made to the hydrologic factors were the most noticeable in the model-computed 5- and 10 -year zones of transport. The changes generally affected the zones of transport for well 11 to a greater degree than for well 26 largely because (1) well 11 is affected by other high-capacity wells nearby, and (2) well 11 is pumping at approximately 4.5 times the rate of well 26 (table 2). Changing the hydrologic factors within the range of expected values did not significantly change the modelcomputed areas for wells 11 and 26. The model-computed zone-of-transport areas generally were within 50 percent of the steady-state average areas (table 10). On the basis of the model results, the hydrologic factors can be ranked in terms of decreasing sensitivity as follows: (1) porosity of the Prairie du Chien Group, (2) horizontal hydraulic conductivity of the St. Peter Sandstone, Prairie du Chien Group, and Jordan Sandstone, (3) anisotropy of the Prairie du Chien Group, (4) streambed conductance, (5) anisotropy of the St. Peter, Prairie du Chien, and Jordan parts, (6) vertical hydraulic conductivity, (7) pumping rates and distribution, (8) porosity of the St. Peter and Jordan Sandstones, and (9) recharge rate. This ranking is based strictly on the results of reviewing the model-computed zones for wells 11 and 26 . A different ranking is possible for different wells and different hydrologic boundaries. 
Based on the model results, the porosity of the Prairie du Chien Group has the greatest effect on the size of the zone-of-transport areas compared to the other hydrologic factors. When the porosity of the Prairie du Chien Group was decreased by 75 percent (to 0.25 ), for example, the 10 -year zone of transport for well 11 increased in area by about 94 percent from 175 to 340 acres (table 10). Such sensitivity has important implications for the Rochester area because the porosity of the Prairie du Chien Group, which is highly variable because of fractures and solution cavities, is not well known.

Adjustments made to most hydrologic factors resulted in expected changes in model-computed zones of transport. Decreasing the vertical hydraulic conductivity of the aquifer system by a factor of 10 , for example, resulted in a corresponding 3-percent increase in the area of the 10-year zone of transport for well 11 (table 10). This increase in area was expected because a reduction in the vertical flow of water requires an increase of the zone of transport to supply ground water to a well at a given pumping rate. Similarly, a 5-percent increase in the porosity of the St. Peter and Jordan Sandstones resulted in a corresponding 9-percent decrease in the 10-year zone of transport for well 11. This decrease in area was expected because the volume of aquifer required to supply ground water to a well decreases as the porosity of the aquifer increases.

Changes made to anisotropy of the Prairie du Chien Group had a significant effect on the model-computed zones of transport. A 300-percent increase in the east-west horizontal hydraulic conductivity (Anisotropy of 1:3) resulted in a 23-percent decrease in the 10-year zone-of-transport area for well 11 (table 10). Because the South Fork Zumbro River is immediately east of well 11, the amount of streamwater induced from the river into the aquifer, and thus to the well, increases when the east-west horizontal hydraulic conductivity is increased. The zones of transport for well 26 are not severely affected by the simulated increase in east-west horizontal hydraulic conductivity because the well is not located close to a stream. On the basis of model results, a 300-percent increase in the north-south horizontal hydraulic conductivity would result in a 17-percent increase in the 10-year zone-of-transport area for well 11. The model-computed zones of transport for the anisotropy analyses are more elongated than the steady-state zones of transport and are oriented in the direction of primary hydraulic conductivity.

The effects of a 25-percent increase in the average pumping rates of all the wells in the model resulted in a corresponding 6-percent increase in the area of the 10-year zone of transport for well 26 and a 6-percent decrease in the 10-year zone of transport for well 11 (table 10). An increase in the zone-of-transport area was expected under increased pumping because an increase in contribution area is required to supply ground water to a well if the pumping rate is increased. The decrease in the zone-of-transport area for well 11 in response to increased withdrawals from all wells is likely related to the proximity of well 11 to other high-capacity wells and to its location near the South Fork Zumbro River.

Increasing streambed conductance likewise decreased the area of the model-computed 10-year zone of transport for well 11 because proportionally more water was captured from the river and less water was withdrawn from the aquifer. The zones of transport for well 26 were relatively unaffected by changes in streambed conductance due to the greater distance of the well from Cascade Creek (table 10).

\section{Comparison of Methods}

The zone-of-transport areas computed by use of most analytical calculations change in arithmetic ratios as the time-of-travel is increased, primarily due to the assumption of a uniform hydraulic gradient. For confined conditions, the area of a 5-year zone of transport should be five times the area of a 1-year zone, and the area of a 10-year zone should be twice that of a 5-year zone. (These ratios should be approximately the same for unconfined conditions as well.) The zones of transport produced by the numerical model, however, did not change arithmetically; areas of the 5-year zones were only about 2.2-2.5 times that of the 1 -year zone and the area of the 10-year zone about 1.5 times that of the 5-year zone (table 3). This departure from the expected ratios may be caused, in part, to the ability of the numerical model to simulate aquifer heterogeneities, threedimensional flow, and interaction between ground water and surface water. Some of the departure, however, is simply related to the scale of the model-the regional model grid is relatively coarse when viewed at the scale of individual wells and over such short travel times. The areas computed by use of the truncated-parabola method also did not change in the expected ratios primarily because most of the area is a function of the calculated zone-of-contribution part of the boundary and hence is unrelated to travel time.

For most methods, the zones of transport for well 11 have areas of about 13-40, 65-100, and 130-175 acres for 1-, 5-, and 10-year travel times, respectively (table 3). Corresponding values for well 26 are about 3-13, 13-25, and 25-30 acres. The numerical model zone-of-transport areas are generally greater than the areas computed by use of most of the analytical methods, particularly for well 26 (table 3). Some of these differences result from the ability of the numerical model to simulate flow in the Prairie du Chien Group and Jordan Formation simultaneously. The lower porosity of the Prairie du Chien Group as compared to the Jordan Sandstone, for example, can be simulated explicitly with the numerical model rather than approximately (by means of an average value for the Prairie du Chien and Jordan parts) as with the analytical methods. Separate analytical calculations would be required to delineate separate zones of transport for the Prairie du Chien and 


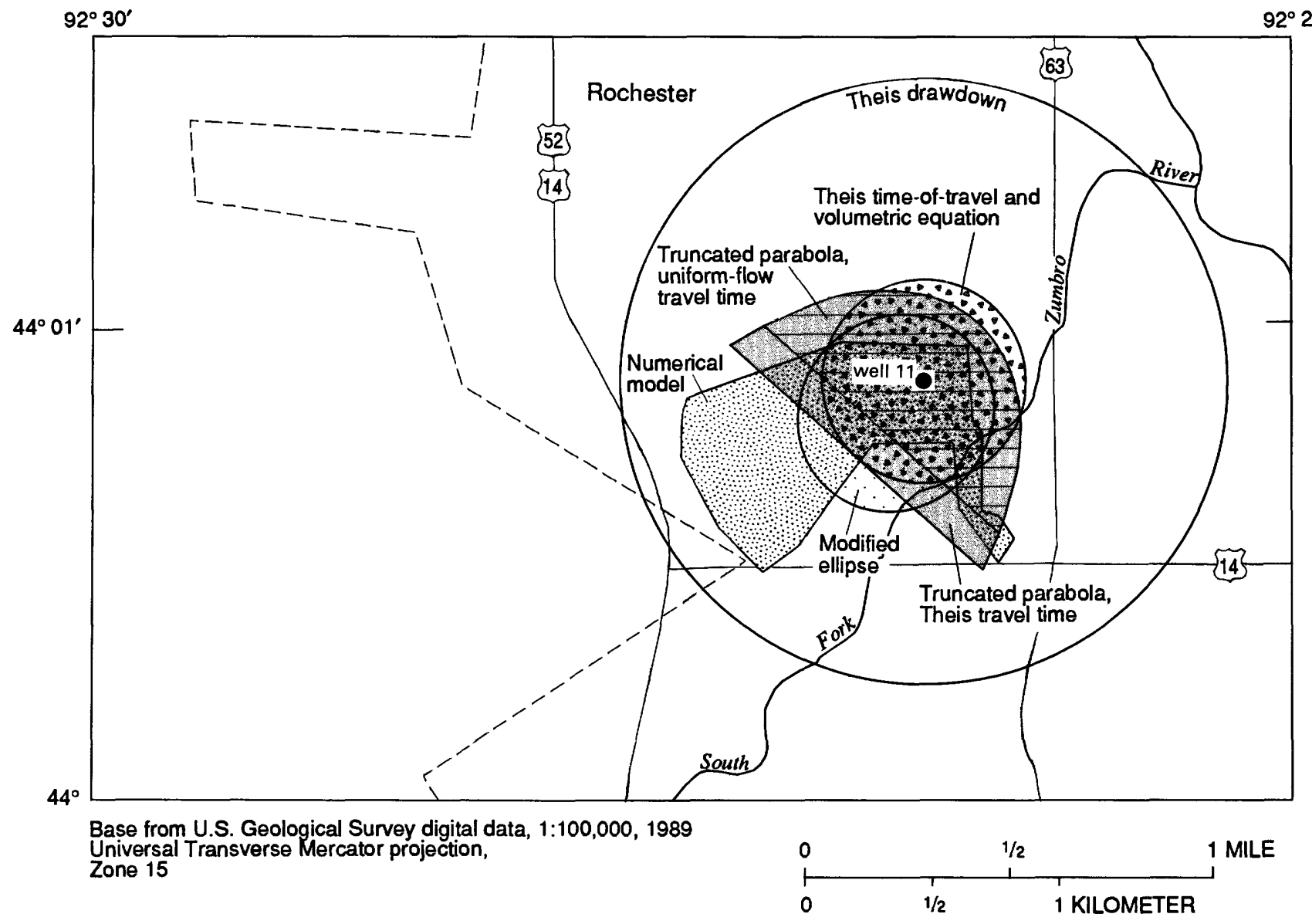

Figure 20. Ten-year zones of transport for well 11.

Jordan parts and thus account for the different hydraulic properties of each formation; such an approach was beyond the scope of this study. Simulation of a complex threedimensional-flow system by use of the numerical model also can result in larger model-computed zones than would be obtained by simulation of only horizontal flow, as assumed for the use of most analytical-calculation methods. The model-computed areas for well 26 are larger than those computed by analytical methods primarily because of locally coarse model subdivision.

Sensitivities of the zones to changes in values of well discharge and porosity computed by use of the Theis time-of-travel, volumetric-equation, and modified-ellipse methods were nearly identical (tables 5, 6, and 9). The sensitivity of the truncated-parabola method, in conjunction with the uniform-flow equation, to changes in horizontal hydraulic conductivity is in contrast to the sensitivity of the methods producing circular zones of transport, however. For the circular-zone-of-transport methods, the gradient toward the well is a function of horizontal hydraulic conductivity and adjusts to the value required to supply a given discharge. For the uniform-flow procedure used in the truncated-parabola method, the hydraulic gradient is inde- pendent of horizontal hydraulic conductivity. Thus, an increase in horizontal hydraulic conductivity results in an increase in flow for a given gradient, which implies an increase in distance traveled per unit time. Finally, because the increased hydraulic gradient caused by pumping at the well is ignored in the uniform-flow procedure, the method necessarily underestimates the true distance to the upgradient boundary of the zone of transport.

Nearly all 1-year zones of transport are more or less symmetric around the wells; thus, even the simple circular zones are comparable to zones computed by use of more sophisticated methods. As travel times increase, however, the ability of a method to construct zones elongated in the upgradient direction becomes increasingly important.

The Theis-drawdown method produced the most anomalous results compared to the other analytical methods tested. The recharge areas computed by use of this method were roughly an order of magnitude larger and an order of magnitude smaller for wells 11 and 26 , respectively, as compared to the zones computed by use of the other methods (table 3). Differences in the 10-year zones of transport for well 11 computed by use of each method are shown in figure 20 . The volumetric-equation method pro- 
duced zones of transport for wells 11 and 26 that are virtually identical to those of the Theis time-of-travel method, despite the vast differences in the underlying assumptions of the two methods.

The main advantage of the fixed-radius methods is that they require less time and expertise to implement compared to the other analytical methods tested. The main disadvantage of these methods, however, is that they do not account for the effect of a regional gradient, which tends to distort zones of transport into elongated shapes.

Although the truncated-parabola method produces zones of transport oriented to the regional flow field, the method theoretically overestimates the contribution area in the downgradient and lateral directions from the well and underestimates the area in the upgradient direction (fig. 20). For situations in which the width of the zone of contribution is quite narrow, such overestimation and underestimation may be insignificant. Except in rare circumstances, however, the distance to the upgradient-zone boundary for any zone of transport should be greater than the distances to the lateral- and downgradient-zone boundaries. Thus, use of this method does not produce acceptable estimates of zones of transport. The truncated-parabola method also produced zones that are, in general, slightly larger than the zones computed by use of the other methods (fig. 20). The uniform-flow procedure for truncating the zone-ofcontribution parabola produced distances of travel that were less than those of all other methods.

Of the two analytical methods that account for orientation to a uniform-flow field, the modified-ellipse method is probably the most accurate method. In flow fields of simple geometry, this method should generate results similar to those of the more sophisticated numerical-modeling method. The zone-of-transport area computed with the modified-ellipse method is virtually identical to those computed with the Theis time-of-travel and volumetric-equation methods.

The numerical-modeling method is the most versatile method available to delineate recharge areas because the model can be used to simulate heterogeneities in a threedimensional flow system that cannot be evaluated with analytical calculations. For example, a numerical model can simulate areal recharge, boundary conditions in the flow system (such as ground-water/surface-water interaction and confining units), areal changes in hydraulic properties of the flow system, and the effects of pumping from other highcapacity wells. A numerical model can also delineate irregularly shaped recharge areas. Except for the hydrogeologic-mapping method, no other method evaluated in this report accounts for withdrawals from other wells. An example of the versatility of the numerical-modeling method is its ability to depict the twin-lobed zone of transport for well 11 (fig. 20), which results primarily from the effects of the nearby river and of withdrawals from nearby high-capacity wells. Although a numerical model is versatile, it is also very complex and requires greater technical experience to construct and considerable time to implement. Use of a model designed specifically to delineate recharge areas is preferable to use of a regional model, such as the model used for this study. The regional model used for this study would be more appropriate for use in delineating recharge areas for wells if the model cells were reduced in size by 50 percent or more. Decreasing the grid scale would improve the accuracy of the model-computed recharge areas. Modification of the existing model was beyond the scope of this study, however.

Study results indicate that the hydrogeologic setting can affect the contributing recharge areas for wells. The close proximity of well 11 to other high-capacity wells, in particular, resulted in significant modification of the modelcomputed recharge areas. If other high-capacity wells were not present nearby, for example, the 10-year zone of transport for well 11 would not have two lobes, as shown in figure 20. Locations of wells near and distant from a river also affected the model-computed recharge areas. If well 11 were not located near the South Fork Zumbro River, the disconnected parts of the zone of contribution shown in figure 12 would not be present. In addition, the pumping rate of a well obviously has a direct effect on the recharge areas computed by use of analytical calculations or the numerical model; a greater pumping rate results in a larger recharge area. The location of wells 11 and 26 in areas where a bedrock confining unit is absent and present, respectively, had little effect on the computed recharge areas because the aquifer is actually unconfined in both areas. If these wells were located in a confined area of the aquifer, however, the recharge areas computed by use of analytical calculations or a numerical model would have been larger compared to the areas computed in unconfined areas of the aquifer.

\section{SUMMARY}

Accurate delineation of areas contributing ground water to wells is an important requisite to protecting ground-water quality; however, comparisons of the results of estimating recharge areas for wells in karst areas by use of various methods have been lacking. A numerical groundwater-flow model for a karstic aquifer, constructed during a previous USGS study, provided an opportunity to compare methods of delineating recharge areas for wells in karst areas.

The areas surrounding a well that are considered relevant to wellhead protection have been categorized as three types of zones: the zone of influence, the zone of contribution, and the zone of transport. These zones are delineated by use of methods with different degrees of complexity, accuracy, and ease of use. Zones of contribution can be delineated either by hydrogeologic-mapping or 
numerical-modeling methods. Zones of transport can be delineated using fixed-radius or variable-shape analytical calculation methods or by numerical modeling. Fixedradius methods evaluated were the Theis drawdown, Theis time-of-travel, and volumetric-equation methods. Variableshape methods evaluated were the truncated-parabola and modified-ellipse methods. The numerical model incorporates data that are representative of heterogeneities in the flow system; consequently, it is assumed that the modelcomputed zones are more accurate than zones computed by the more simplified analytical methods.

Recharge areas were calculated for two municipal wells that tap the karstic St. Peter-Prairie du Chien-Jordan aquifer at Rochester in southeastern Minnesota. Well 11 is near the South Fork Zumbro River where the DecorahPlatteville-Glenwood confining unit is absent and well 26 is distant from streams where the confining unit is present.

Zones of contribution delineated by use of the hydrogeologic-mapping method are wedge-shaped areas extending from wells upgradient to the ground-water divide. The zone of contribution for well 11 during summer months covers about 13,440 acres, whereas the zone during winter months covers about 4,100 acres. The zones of contribution delineated by use of the numerical model are substantially different than the zones delineated by hydrogeologic mapping. The model-computed zone of contribution for well 11 is discontinuous and covers an area of about 2,180 acres. The disconnected contribution areas for well 11 result from the capture of ground water by nearby high-capacity wells and from ground-water discharge to the South Fork Zumbro River. The model-computed zone of contribution for well 26 does not extend upgradient to the ground-water divide. Results of the numerical model for wells 11 and 26 illustrate the versatility and advantages of the numerical-modeling method in simulating heterogeneities in the flow system that cannot be evaluated by use of the hydrogeologic-mapping method.

The zone-of-transport areas change arithmetically between the different travel times for each method with the exception of zones delineated by use of the numericalmodeling and truncated-parabola methods. The Theis drawdown method yielded the most anomalous results; zone areas differed by an order of magnitude from zones computed by the other methods. The zone-of-transport areas computed by use of the numerical model are generally larger than the areas computed by use of the analytical methods. These differences are attributed in part to coarse model subdivision.

Nearly all 1-year zones of transport are symmetrical around the wells; hence, the results from fixed-radius methods are comparable to those from the variable-shape and numerical-modeling methods. At longer travel times, however, the methods that compute variably shaped zones represent hydrogeologic conditions more accurately than do the fixed-radius methods. Of the two analytical methods that allow for orientation to a uniform-flow field, the modified-ellipse method is probably more accurate. The modified-ellipse method also yielded results similar to those from the more sophisticated numerical-modeling method. The numerical-modeling method is the most versatile method because it cannot only simulate heterogeneities in the flow system, withdrawals from other high-capacity wells, hydrologic boundary conditions, and regional hydraulic gradients, but also delineate irregularly-shaped zones. The zones delineated by use of the numerical model generally have an angular outline. This angularity is caused by coarseness of model subdivision.

The zones of transport computed with nearly all the analytical methods were more sensitive to changes in porosity than to changes in other hydrogeologic properties. On the basis of the numerical model results, hydrologic factors can be ranked in terms of decreasing sensitivity as follows: (1) porosity of the Prairie du Chien Group, (2) horizontal hydraulic conductivity of the St. Peter Sandstone, Prairie du Chien Group, and Jordan Sandstone, (3) anisotropy of the Prairie du Chien Group, (4) streambed conductance, (5) anisotropy of the St. Peter, Prairie du Chien, and Jordan parts, (6) vertical hydraulic conductivity, (7) pumping rates and distribution, (8) porosity of the St. Peter and Jordan Sandstones, and (9) recharge rate.

Numerical models should be used with caution when delineating extremely complex zones of contribution due to the assumptions, uncertainties, and limitations in a typical numerical model, particularly if the model-computed zones are intended for use in regulatory concerns. The numerical model used in this investigation was not designed for delineating recharge areas to wells. Therefore, results of the numerical modeling are not necessarily better than the results of hydrogeologic mapping. From a management perspective, numerical models ultimately are most valuable as educational tools to aid in the design of strategies and approaches to protecting ground-water quality.

Study results indicate that well location can affect the recharge area. The proximity of a well to other highcapacity wells, in particular, resulted in substantial modification of the model-computed recharge areas. Proximity of a well to a river resulted in a disconnected zone of contribution, whereas an increase in pumping rate resulted in an increase in recharge area. Computed recharge areas for a confined part of the aquifer would undoubtedly differ from analytical and model-computed recharge areas for an unconfined part of the aquifer.

\section{REFERENCES}

Baker, D.G., and Kuehnast, E.A., 1978, Climate of Minnesota Part X, Precipitation normals for 1941-70: Minnesota Agricultural Experiment Station Technical Bulletin 314, 15 p. 
Balaban, N.H., ed., 1988, Geologic atlas, Olmsted County, Minnesota: Minnesota Geological Survey Atlas C-3, 9 sheets, scale 1:100,000.

Bear, J., 1979, Hydraulics of groundwater: New York, McGrawHill, 567 p.

Brown, R.H., 1963, The cone of depression and the area of diversion around a discharging well in an infinite strip aquifer subject to uniform recharge: U.S. Geological Survey WaterSupply Paper 1545-C, p. 669-685.

Delin, G.N., 1990, Hydrogeology and simulation of ground-water flow in the Rochester area, southeastern Minnesota 1987-88: U.S. Geological Survey Water Resources Investigations Report 90-4081, 102 p.

Delin, G.N., and Woodward, D.G., 1984, Hydrogeologic setting and the potentiometric surfaces of regional aquifers in the Hollandale Embayment, southeastern Minnesota, 1970-80: U.S. Geological Survey Water-Supply Paper 2219, $56 \mathrm{p}$.

Freeze, R.A., and Cherry, J.A., 1979, Groundwater: Englewood Cliffs, N.J., Prentice-Hall, Inc., 604 p.

Javandel, I., Doughty, C., and Tsang, C.F., 1984, Groundwater transport: Handbook of mathematical models: Washington, D.C., Water resources monograph 10, American Geophysical Union, $228 \mathrm{p}$.

McDonald, M.G., and Harbaugh, A.W., 1988, A modular threedimensional finite-difference ground-water flow model: U.S.
Geological Survey Techniques of Water-Resources Investigations, Book C, Chapter A1, 586 p.

Morrissey, D.J., 1989, Estimation of the recharge area contributing water to a pumped well in a glacial-drift, river-valley aquifer: U.S. Geological Survey Water-Supply Paper 2338, $41 \mathrm{p}$.

Norvitch, R.F., Ross, T.G., and Brietkrietz, Alex, 1973, Water resources outlook for the Minneapolis-St. Paul metropolitan area, Minnesota: Metropolitan Council of the Twin Cities Area, $219 \mathrm{p}$.

Pollock, D.W., 1989, Documentation of computer programs to compute and display pathlines using results from the U.S. Geological Survey modular three-dimensional finitedifference ground-water flow model: U.S. Geological Survey Open-File Report 89-381, 188 p.

Ruhl, J.F., 1989, Flow of ground water through fractured carbonate rocks in the Prairie du Chien-Jordan aquifer, southeastern Minnesota: U.S. Geological Survey Open-File Report 89-253, 2 p.

Strack, O.D.L., 1989, Groundwater mechanics: Englewood Cliffs, N.J., Prentice-Hall, Inc., 732 p.

Todd, D.K., 1980, Groundwater hydrology: New York, N.Y., John Wiley \& Sons, 535 p.

U.S. Environmental Protection Agency, 1987, Guidelines for delineation of wellhead protection areas: U.S. Environmental Protection Agency Office of Ground-Water Protection, Washington, D.C., EPA 440/6-87-010, 189 p. 